\title{
Financial impact analysis of going public at the Warsaw Stock Exchange: Using Fuzzy Set Theory to understand behaviours of mature companies
}

\author{
Martina SKALICKÁ \\ Brno University of Technology, Faculty of Business and Management, Brno/Czech Republic \\ Marek ZINECKER \\ Brno University of Technology, Faculty of Business and Management, Brno/Czech Republic \\ zinecker@fbm.vutbr.cz \\ Michał B. PIETRZAK \\ Nicolaus Copernicus University, Faculty of Economic Sciences and Management, \\ Toruń/Poland \\ Tomáš MELUZín \\ Brno University of Technology, Faculty of Business and Management, Brno/Czech Republic \\ Mirko DOHNAL \\ Brno University of Technology, Faculty of Business and Management, Brno/Czech Republic
}

\begin{abstract}
In this paper, we intend to contribute evidence in regard to going public financial impact and thus motivation on a sample of mature companies that launched an IPO at the Warsaw Stock Exchange between 2005 and 2015. First, we review recent literature focusing on financial and non-financial consequences of an IPO. Next, we use fuzzy sets and fuzzy reasoning to define a "mature" company and assess financial consequences of going public. Our main conclusion is that the majority of Polish mature companies use an IPO as a channel how to raise capital and accelerate their investments and growth. This contradicts many previous empirical studies highlighting that the main motivation of mature companies to go public is to use the capital raised within an IPO to rebalance their capital structure.
\end{abstract}

Keywords: IPO, Going Public, Warsaw Stock Exchange, Motivation, Poland, Fuzzy Sets, Fuzzy Reasoning.

Please cite the article as follows: Skalická, M, Zinecker, M, Pietrzak, M.B., Meluzín, T., Dohnal, M., (2019), "Financial impact analysis of going public at the Warsaw Stock Exchange: Using Fuzzy Set Theory to understand behaviours of mature companies", Management \& Marketing. Challenges for the Knowledge Society, Vol. 14, No. 1, pp. 59-79. DOI: 10.2478/mmcks-2019-0005.

\section{Introduction}

It is generally agreed that companies go public when they are sufficiently mature to withstand the scrutiny of investors, institutional rating agencies, business magazines, or high-tech information intermediaries (Ritter, 1991; Chemmanur and Fulghieri, 1999; Pastor and Veronesi, 2003). Although the term "mature company" is widely used in the literature, it is not unambiguously defined. There is no fixed definition of how the "mature" company 
should be old and what growth rate or what size it is supposed to have. As a rule, the "mature" company is defined only verbally and is characterised by qualitative features (e.g. Dickinson, 2011; Reiners, 2004).

This paper is an attempt to contribute to the discussion on financial consequences and thus motivation of going public. We join several recent studies and examine the impact of going public on a sample of 96 mature Polish companies, which conducted an initial public offering (IPO) between 2005 and 2015 in the Main Market of the Warsaw Stock Exchange (WSE). First, we use fuzzy sets and fuzzy reasoning to define a "mature" company. Next, we deal with the issue what the investment and financial policy of a sample of mature Polish companies within the post-IPO stage is. Are the financial funds rather used for fresh investments to strengthen the earning potential of the company or do the CFOs tend to use the raised capital for re-structuring the existing capital structure? Even in this case we struggle with the vagueness in researchers' judgements and therefore we believe the methodology based on fuzzy set theory is appropriate to assess financial consequences of going public.

Pagano et al. (1998), Chun and Smith (2002), Jargot (2006) and many others analysed motives and financial consequences of an IPO while applying logit and probit methodologies which are two most common techniques for estimation of models with a dichotomous dependent variable (Greene, 2003). Both techniques are used to create predictive models that an event will occur and both models are estimated by maximum likelihood; goodness of fit and inferential statistics is based on the log likelihood and chi-square test statistics (Jargot, 2006). However, these techniques have significant limitations consisting in working with precise and certain information. For example, logistic regression could not be used to determine how old a "mature" company should be or what growth rate or size it is supposed to have. Researchers have to attempt to convert the measurements of age, growth and size into discrete categories characterised by qualitative features.

Therefore, in this study we deliver empirical evidence based on fuzzy set theory. While using this concept we first identify a group of entities defined as "mature companies" and next deal with financial consequences of going public. The issue of the membership of a company to a particular category has to be decided by the fuzzy logic working with the level of affiliation of a surveyed entity to the interest category. The fuzzy research approach overcomes the shortcomings of the ambiguous definition of the boundaries delimiting the category of e.g. a "mature" company or "high" growth rate of the company. The fuzzy set theory, introduced by Zadeh (1965), is commonly applied to deal with imprecise and uncertain information in the real-world problems; it is more suitable for qualitative assessment than classical evaluation methods working with precise values (Lin and Chen, 2004; Wang and Chuu, 2004).

This study extends the IPO in the way that to our knowledge we are the first who attempt to uncover the possible motivations to go public by applying the fuzzy set approach. We use data on the ex-ante and ex-post financial characteristics of surveyed sample of companies. We find support for the theory that mature Polish companies use an IPO as a channel how to raise capital and accelerate their investments and growth. This contradicts many previous empirical studies highlighting that the main motivation of mature companies to go public is to use the capital raised within an IPO to rebalance their capital structure. 


\section{Literature review}

Substantial academic literature interprets the decision of a company to conduct an initial public offering (IPO) as essential (e.g. Myers, 1984; Pagano et al., 1998; Brau and Fawcett, 2006; Jargot, 2006; Bancel and Mittoo, 2009; Peterle and Berk, 2016; Meluzín et al., 2016, $2018 a, b, c)$. Nevertheless, the pecking order theory emphasises that this form of financing does not come into consideration until the possibilities of internal funding have been exhausted, as well as external resources, e.g. in the form of bank loans (Myers, Majluf, 1984; Michalak, 2016; Włodarczyk et al., 2018; Manuylenko et al., 2018). This is due to the costs of the share capital perceived to be higher by the financial theory compared to the costs of debt financing. Also for this reason, IPO implementation may be expected to be the last option considered when deciding on the manner of financing corporate investments, which is more likely to be used in the case of large and mature companies where an adverse selection problem is less accentuated (e. g. Ritter, 1991; Chemmanur and Fulghieri, 1999; Pastor and Veronesi, 2003; Ivanová, 2017; Ślusarczyk, 2018).

There is a broad range of motives why companies implement the IPO, being of both financial and non-financial character (Sosnowski, 2017; 2018). Ritter and Welch (2002) emphasise that the main motive is to raise capital for growth. Kim and Weisbach (2008), who examined the IPO in 38 countries, nevertheless add that most companies obtain a large volume of capital through the IPO, yet he scale of its use ranges from funding the development to rebalancing leverage. Pagano et al.(1998) also sees the main reason in rebalancing the company's capital structure after a period of high investment and dynamic growth, and further emphasises that going public improves the bargaining position of issuers towards banks and reduces debt costs and the share of bank financing in the capital structure. Auret and Britten (2008) report that IPO yields are often used to repay existing debts. Helwege and Liang (2004) add that the IPO may also represent a form of total or partial exits of the existing shareholders, whether they are in the role of company's founders, business angels, or venture capitalists.

A number of other studies indicate that the motives for the IPO implementation may consist in the efforts to build public relations; this may include, for example the visibility of the company in the media, forming the desired perception of the enterprise in the eyes of the public, or influencing the perception of the business sector in relation to its viability and risk (Brau et al., 2003, Maksimovic, Pichler, 2001; Kiseláková et al., 2015; Bikas, Saponaitė, 2018; Wawryszuk-Misztal, 2017; Valaskova et al., 2018).

The possible IPO motive can also include optimising the assets portfolio of the existing shareholders who retain control over the company, yet selling part of the shares at the same time frees up their capital fixed in the shares of the issuing company, which they then use for other investments, repayment of debts, payment of minority shareholders etc. (Paeglis , Veeren, 2013; Wrońska-Bukalska, \& Kaźmierska-Jóźwiak, 2017). Pratt and Grabowski (2008) also state that the IPO is the last option considered in deciding on how to finance development business investments due to the high cost of equity.

Brau and Fawcett (2006) conclude that the key motive of the IPO implementation in the US market conditions consists in the possibility of using the proceeds of the issue for future mergers and acquisitions, expanding the possibilities of obtaining additional funding in the future, or increasing the attractiveness of the company in recruiting managerial talent through share options. Kim and Weisbach (2008) focus on the perspectives of existing 
shareholders for whom it is important to create a market for the shares of the issuing company, thus substantially increasing their liquidity.

According to Helwege and Liang (2004), initial public offerings are more frequent in sectors achieving rapid growth. The reason is usually the urgent need for capital to realise the planned investments (or acquisitions) in order to maintain a position in the growing market and at the same time to reduce the risk on the side of the existing shareholders, as the rapid development of the company commonly reduces the capacity to predict future developments with sufficient precision.

Bancel and Mittoo (2009), who examined the IPO motives in 12 European countries, conclude that companies most often implement IPOs to raise capital for their development investments, yet strategic considerations are also affected by efforts to improve reputation, financial credibility and financial flexibility.

In the CEE region, research into IPO motives has been limited to a few studies. Meluzín and Zinecker (2014), as well as Meluzín et al. (2016, 2018a,b,c), who performed survey-based research using the primary data from the environment of the Czech and Polish capital markets, emphasise the financial motive, both among companies that have already implemented the IPO and those which may be labelled as IPO candidates. Non-financial motives stemming from the efforts to strengthen the company's publicity and value the company's shares are also identified as essential.

Very frequently, relevant literature mentions the fact that IPO motives are different for companies which are in the growth phase of their life cycle and may therefore be described as "young", and for businesses which have already undergone a swift phase of initial development, being labelled as "stabilized" or "mature". For example, Brau and Fawcett (2006) point out the fact that when deciding on the IPO, "young" US firms, compared to their "mature" peers, are statistically more significantly motivated by the possibility to use public shares for future mergers and acquisitions, the possibility to determine the market value of their shares, and the status of a publicly traded company in order to enhance image and publicity. For the purposes of dividing the examined companies into "mature" and "young", the authors used the median age of all entities included in the research sample.

The results of the Bancel and Mittoo (2009) study suggest that "young" European businesses, in addition to strengthening publicity, place greater emphasis on the possibility of raising capital in the IPO process, which distinguishes them from "mature" companies, which more often refer to the possibility of "reducing the firm leverage", i.e. using IPO yields for the purposes of financial restructuring. Meluzín et al. (2016) have reached similar results. In addition to reducing indebtedness and strengthening the bargaining power towards external capital providers, there are the motives with a statistically significant support among the "mature" Polish companies surveyed. For the purposes of categorising companies (young vs. "mature"), both European studies repeatedly use the median age of the companies included in the research sample.

In addition to the above-mentioned empirical studies, the differences in the motivation to implement the IPO among "mature" and "young" companies are addressed in a number of theoretical models (e. g. Chemmanur and Fulghiery, 1999, Pagano et al., 1998, or Rajan, 1992). In general, it is assumed that companies do not initiate an IPO until sufficient information about them has been accumulated on the capital market to mitigate information asymmetries. Therefore, the more "mature" the enterprise is, the higher the probability of 
the IPO. For more mature businesses, it is also assumed that the capital raised will be used primarily to restructure the capital structure instead of implementing development investment projects. In the case of mature companies, initial public offerings are frequently implemented only after a large-scale investment phase which has been funded, for example, by bank loans, in order to make use of the growth already achieved to raise the attractiveness of the issue to potential investors. This may lead to a greater effort concerning the IPO timing, although the growth potential of issuing mature companies tends to be significantly exhausted. The assumption of lower attractiveness of the initial public offering of mature businesses intending to raise capital is also due to easier access to alternative sources of funding compared to early-stage enterprises. The above facts support the thesis that mature businesses preferentially use the capital raised for financial restructuring. On the contrary, the motivation of young businesses is to raise capital to finance further business development.

When defining life cycle phases, i.e. their number and characteristics, the current theory is inconsistent. The main issue in identifying the life stage of a particular company consists in the fact that the existing models often work with quality characteristics which are very difficult to quantify (Konečný and Zinecker, 2017). For example, models based on quantitative variables include the one defined by Dickinson (2011). The life cycle phases of an enterprise are determined by a combination of positive and negative cash flow values from operating, investment and financial activities. On the other hand, in his model, Reiners (2004) proposes the use of relative performance indicators reflecting the year-on-year change in the growth of assets, sales and cash flow. This model also defines interval values for identifying the individual stages of the life cycle. Konečný and Zinecker (2015) recommend using the modified form of the Boston Matrix to identify the life cycle of a company. In the model, the life cycle phases are identified based on relative revenue growth where the growth rate of corporate sales is compared to the market growth and depending on the relative market share where the market share of an enterprise is compared to the volume of corporate assets. The model is limited by the assumption that the life cycle of an enterprise is identical to the life cycle of all its products.

During the life cycle, both the company's capital structure and its capital costs are transformed. Reiners (2004) states that the cost of equity has a declining trend over the life cycle, as shareholders' investment risk decreases. On the other hand, Hasan et al. (2016) believes that the course of equity cost over the company's life cycle has the form of a U-shape and thus corresponds to the trend of the debt capital costs, or the weighted average cost of capital. Following the Dickinson's model for determining the life cycle stage of the company, Faff et al. (2016) indicates that the volume of investments and issues of equity decreases in the course of the company's life cycle. The largest share in the capital structure is reached by the debt in the stages of market entry and growth, so that the value of this indicator falls in the phase of stabilization (maturity) and decline.

The rest of this paper proceeds as follows. First, we provide an overview of the methodological approach. Next, we present and interpret research findings. The final sections discuss and summarise the main conclusions. 


\section{Methodology}

In this paper, we empirically investigate the financial consequences of going public on a sample of 96 mature Polish companies which conducted an initial public offering between 2005 and 2015 in the Main Market of the Warsaw Stock Exchange. The source of financial data is the Amadeus Database provided by Bureau van Dijk. To deliver evidence on mature companies and financial consequences of going public, we formulate the following research questions: What would be an appropriate definition of a mature company within the defined subsample? What is the investment and financial policy of mature companies within the postIPO stage? Are the financial funds rather used for fresh investments to strengthen the earning potential of the company or do the CFOs tend to use the raised capital for re-structuring the existing capital structure?

We used fuzzy sets and fuzzy reasoning to define a "mature" company and to assess financial consequences of going public. This research approach deals with indefinite quantification of a set of variables. The fuzzification of variables allowed us to query the knowledge database and to work with results, which are further used as inputs to search for parameters of typical units. In parallel with this approach, ordinary least squares (OLS) method was applied. The results, however, are not relevant as the overwhelming majority of input coefficients were statistically not significant. The validity of using OLS is reduces by the data characteristics because the time series is characterized by a small number of observations. The inappropriateness of the OLS approach is also enhanced by the fact that within the survey sample just a minority of companies can be defined as mature companies in terms of all characteristics, as defined by the review. Therefore we believe that our data set is suitable for applying the methodology based on fuzzy set theory.

\section{Fuzzy Set Theory}

A fuzzy set theory is based on the premise that the key elements in human thinking are not numbers but words. The most important features of human thinking is the not yet wellknown ability how to extract from a collection of masses of data only such items of knowledge which are relevant to the task at hand, see e.g. (Zimmermann, 1987; Skvarciany et al., 2018).

Let us take as an example of a verbal variable a size of an Industrial Production Growth (IPG). To quantify expert knowledge a set of verbal values, i.e. a dictionary, is needed. This verbal IPG dictionary could include the following set of verbal quantifiers:

Very Low, Low, Medium, High, Very High, Extremely High, etc.

A linguistic value is transformed into a fuzzy set by the specification of a grade of membership. For example, a verbal value medium of the IPG is transformed into a fuzzy set by the grade of membership function shown in Fig. 1. A typical medium size of the IPG is: $\mu_{\mathrm{A} 5}(\mathrm{x})=1$ if and only if $\mathrm{b}<\mathrm{IPG}<\mathrm{c}$

Where the values of the IPG size (1) belong to the fuzzy set medium size IPG with the grade of membership equal to 1 . Therefore they are a typical medium IPG size (see Fig. 1).

There are two fuzzy intervals a $<$ IPG $<$ b, $c<$ IPG $<$, see Fig. 1 . It means that the relevant grade of membership is in the interval $<0,1>$ :

$\mu_{\text {medium }}(\mathrm{x}) \epsilon<0,1>$ if and only if a $<$ IPG $<\mathrm{b}, \mathrm{c}<\mathrm{IPG}<\mathrm{d}$

is the grade of membership.

These intervals represent such numerical values, which belong partially to the fuzzy set medium size IPG. 


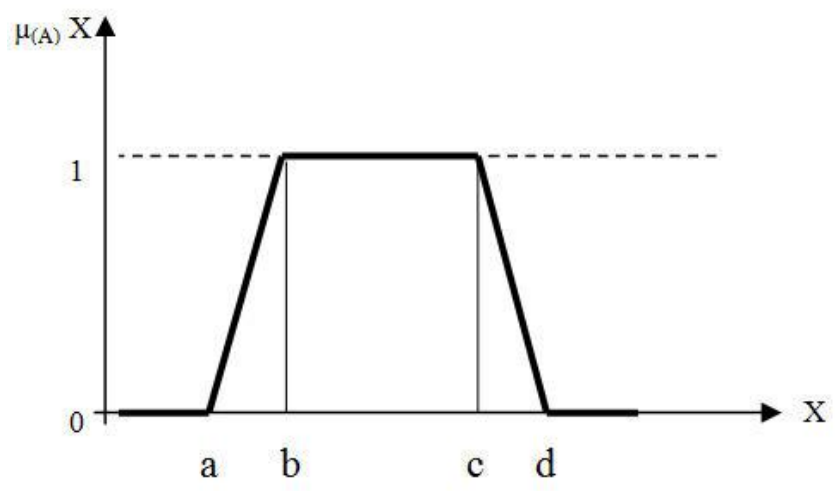

Figure 1. Trapezoidal fuzzy number

Source: Dohnal and Dohnalova (1992)

A fuzzy model is a set of conditional statements:

If $A_{11}$ and ..........and $A_{1 n}$ then $B_{1}$ or

If $A_{21}$ and ..........and $A_{2 n}$ then $B_{2}$ or

If $A_{m} 1$ and ........and $A_{m n}$ then $B_{m}$

Where the fuzzy sets

$A_{i, j}, B_{i} ; i=1,2, . . m, j=1,2, \ldots n$

Are one-dimensional fuzzy sets and can be easily specified or/and modified using points $a, b$, $c$, and $d$ (see Fig. 1) for each set.

The model (3) describes a $n$-dimensional unknown function

$\mathrm{Y}=\mathrm{f}\left(\mathrm{X}_{1} \ldots . . . \mathrm{X}_{\mathrm{n}}\right)$

Where the fuzzy sets $A_{i}$ represent independent variables $X_{i}(5)$ and fuzzy sets B represent the dependent variable Y.

A given (chosen) $n$-dimensional fuzzy set $\mathrm{Q}$ :

$\mathrm{Q}=\mathrm{Q}_{1}$ and $\mathrm{Q}_{2}$ and...and $\mathrm{Q}_{\mathrm{n}}$

is a fuzzy query. This query can be answered by the fuzzy model (4).

A similarity $s$ of two $n$-dimensional fuzzy sets $\mathrm{V}, \mathrm{W}$ is:

$$
s(n, V, W)=\min \max \min \left(\mu_{v_{j}}\left(X_{j}\right), \mu_{w_{j}}\left(X_{j}\right)\right)
$$

Where $\max \left\{\min \left[\mu_{\mathrm{V}_{j}}\left(\mathrm{X}_{\mathrm{j}}\right), \mu_{\mathrm{W}_{\mathrm{j}}}\left(\mathrm{X}_{\mathrm{j}}\right)\right]\right\}$ represents the fuzzy intersection of two one-dimensional fuzzy sets $\mathrm{V}_{\mathrm{j}} \cap \mathrm{W}_{\mathrm{j}}$.

The similarity s of the fuzzy set $\mathrm{R}_{\mathrm{i}}$,

$\mathrm{R}_{\mathrm{i}}=\mathrm{A}_{\mathrm{i}, 1}$ and $\mathrm{A}_{\mathrm{i}, 2} \ldots$... and $\mathrm{A}_{\mathrm{i}, \mathrm{n}}$ ( (see (4))

And the query $Q(6)$ is:

$\mathrm{s}\left(\mathrm{n}, \mathrm{Q}, \mathrm{R}_{\mathrm{i}}\right)$

Set $w(Q)$ of those statements (4) which are similar to the query $Q$ is:

$\mathrm{w}(\mathrm{Q})=\{\mathrm{i} \mid \mathrm{s}(\mathrm{n}, \mathrm{Ri}, \mathrm{Q})>0\}$

The answer of the fuzzy model R (4) to query $Q(6)$ is a modification of the following union of B sets (see (4)):

$$
R=\underset{i \in w(Q)}{U} B_{i}
$$


Let us suppose that only two statements out of m statements (4) are similar to query Q (6). To be specific, let the first and the second statements be similar. Therefore, see (10).

$\mathrm{w}(\mathrm{Q})=\{1,2\}$

Let the similarities $s(9)$ be,

$s_{1}=s\left(n, R_{1}, Q\right)=0,6 ; s_{2}=s\left(n, R_{2}, Q\right)=0,3$

Let the variable Industrial Production Growth (IPG) be the dependent variable and $\mathrm{B}_{1}(\mathrm{M})$ be EFGH and $B_{2}(M)$ be IJKL, see Fig. 2 and (4). The fuzzy "answer" R(11) of the model (4) is represented by the fuzzy set $\mathrm{EW}_{1} \mathrm{~W}_{2} \mathrm{HIW}_{3} \mathrm{~W}_{4} \mathrm{~L}$ (Fig. 2).

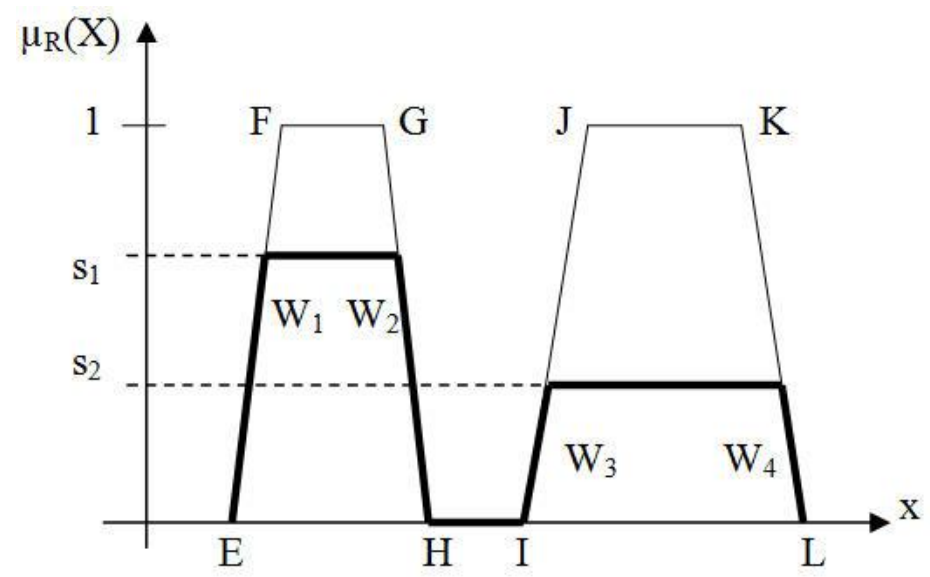

Figure 2. Example of fuzzy answer $R$ to the query $Q$ Source: Dohnal and Dohnalova (1992)

Quite frequently, a fuzzy model is only a part of a more complex and perhaps conventional model. It means that the fuzzy answer $\mathrm{R}$ is an information item that is used for further conventional numerical calculations. Any conventional calculation is based on numbers, therefore fuzzy $\rightarrow$ numerical value

The interface is needed to generate a numerical representation of fuzzy answer R_(11). There are a number of different interfaces described in literature, see e.g. (Dohnal and Dohnalová, 1992). However, this paper requires simplicity. Therefore a centre of gravity CG of the corresponding area (see Fig. 2).

$\mathrm{C}_{\mathrm{GQ}}\left(\mathrm{EW}_{1} \mathrm{~W}_{2} \mathrm{HIW}_{3} \mathrm{~W}_{4} \mathrm{~L}\right)$

is chosen as the numerical representation.

\section{Fuzzy Knowledge Base}

A FES (Fuzzy Expert System) is a computer programme which can perform the above described fuzzy reasoning for any set of statements (3) and corresponding dictionaries (4). The set of statements (3) and the dictionaries (4) represent fuzzy knowledge base (FKB): $\mathrm{FKB}=[$ Statements (3), Dictionaries (4)]

It is obvious that FES is universal as it is based on universally applicable fuzzy reasoning algorithm (11). The FKB is specific, as it represents a specific fuzzy model $(3,4)$. 
FKB is inserted into a FES. It must be a simple software procedure. Such FES can be used to answer fuzzy query $Q(6)$

$\mathrm{Q}(6) \rightarrow \mathrm{FES}\{\mathrm{FKB}\} \rightarrow \mathrm{R}(11)$

FKB must be developed.

\section{IPO Fuzzy Model}

It is obvious that each FKB is specific. Its specificity is due to the set of variables and the set of variables is predetermined by a studied IPO task. Moreover, the available set of IPO knowledge items must be interpreted as a set of fuzzy conditional statements. There are two basic approaches to fuzzy interpretations of the IPO knowledge: 1) expert interpretation and 2) fuzzy interpretation of non-modified IPO records.

The expert interpretation is based on verbal descriptions of experts' feelings generated by the very nature of verbal quantifications. This approach is highly likely to increase the vagueness of the resulting fuzzy model, for details see e.g. Dohnal and Dohnalová (1992). This is the main reason why the non-modified alternative of fuzzy model development was chosen.

Let us suppose that a set of M relevant $n$-dimensional records of IPO is available. Many IPO variables are non fuzzy by their very nature. For example TAS (Total Assets Size) given in EUR. This value is known absolutely precisely and therefore its fuzzy interpretation can be accurate, i.e. non-fuzzy:

$\mathrm{a}=\mathrm{b}=\mathrm{c}=\mathrm{d}$, see Fig. 1 (You-Shyang Chen and Ching-Hsue Cheng, 2012).

However, common sense indicates that for reasoning purposes TAS interpretation can be partially fuzzy:

$X$ - specific numerical value of TASS; e.g. $X=1.82$

$\mathrm{b}=\mathrm{X}=\mathrm{c}$, see Fig. 1

$\mathrm{a}=(1-\varepsilon) X ; d=(1+\varepsilon) X ;$ Dincer et al. (2016).

It means that the fuzzy set (R2) is represented by a triangle and not by a trapezoid as in Fig. 1.

The following variables were chosen by a team of experts, see Table 1.

Table 1. Variables, Abbreviations and Dimensions

\begin{tabular}{|c|c|c|}
\hline Variable & Abbreviation & Dimension \\
\hline Total Assets (it-1) & $\mathrm{B} 20$ & logarithm of assets (in '000 EUR) \\
\hline Leverage (it-1) & D20 & total debt over total debt plus equity \\
\hline Shareholders Funds (it-1) & F20 & in '000 EUR \\
\hline $\mathrm{ROA}_{\text {(it-1) }}$ & L20 & EBITDA over total assets \\
\hline Growth (it/it-1) & $\mathrm{N} 24$ & annual growth rate in sales computed as (it/it-1) \\
\hline Investments (it/it-1) & 028 & growth rate of fixed assets computed as (it/it-1) \\
\hline Leverage (it) & $\mathrm{R} 20$ & total debt over total debt plus equity \\
\hline Age (it) & $\mathrm{U} 20$ & number of years from incorporation till it \\
\hline Growth (it+1/it) & Y24 & annual growth rate in sales computed as (it+1/it) \\
\hline Investments (it+1/it) & $\mathrm{Z}$ & growth rate of fixed assets computed as (it+1/it) \\
\hline
\end{tabular}

Source: Authors' own research.

The fuzzy knowledge base has 94 statements and 10 variables. Each variable has its dictionary. Each dictionary is given by the corresponding numerical values given in Appendix 
1 and by the relevant values of the fraction $\varepsilon\left(R_{2}\right)$. The following fractions are used in the text, see Table 2.

Table 2. Relevant Values of the Fraction $\varepsilon$

\begin{tabular}{|c|c|c|c|}
\hline Variable & Abbreviation & Definition of $\varepsilon$ & Auxiliary defining variable $i$ \\
\hline Total Assets (it-1) & $\mathrm{B} 20$ & 0.43 & - \\
\hline Leverage (it-1) $_{\text {(i) }}$ & D20 & $=\mathrm{i} / \mathrm{X}$ & 0.05 \\
\hline Shareholders Funds (it-1) & F20 & 0.42 & - \\
\hline $\mathrm{ROA}_{(\mathrm{it}-1)}$ & L20 & $=\mathrm{i} / \mathrm{X}$ & 5 \\
\hline Growth (it/it-1) & $\mathrm{N} 24$ & $=\mathrm{i} / \mathrm{X}$ & 0.5 \\
\hline Investments $_{(\mathrm{it} / \mathrm{it}-1)}$ & 028 & $=\mathrm{i} / \mathrm{X}$ & 0.25 \\
\hline Leverage $_{(i t)}$ & $\mathrm{R} 20$ & $=\mathrm{i} / \mathrm{X}$ & 0.05 \\
\hline Age $_{(i t)}$ & $\mathrm{U} 20$ & 0.23 & - \\
\hline Growth $_{\text {(it+1/it) }}$ & Y24 & $=\mathrm{i} / \mathrm{X}$ & 0.5 \\
\hline
\end{tabular}

Source: Authors' own research.

\section{Fuzzy Queries}

The algorithm of answering queries (16) is relatively simple and very flexible. For example, there is no need to specify all variables, see Tab. 1. Some variables can be ignored. This flexibility can be easily used to perform a dialogue loop:

Investor $\rightarrow$ FES $\{\mathrm{FKB}\} \rightarrow$ Investor $\rightarrow$ FES $\{\mathrm{FKB}\} \rightarrow$ etc.

However, to take an advantage of the fuzzy flexibility just a subset of $n$ variables (5) is used. For example, just the following variables (see Tab. 1) are used to specify the query: B20, F20, L20, U20. Just one variable V (5) represents the answer R(11), see (16). It means that the function (5) is modified as follows: $028=f(B 20, F 20, L 20, U 20)$

The expert system will then reply an answer with (028) - based on the information incorporated in the fuzzy knowledge base. The result is calculated as the position of the centre of gravity of the variable fuzzy set measured from the origin of the axis $x$.

When defining the concept of the "mature company", we follow the relevant literature (e.g. Dickinson, 2011; Reiners, 2004; Konečný and Zinecker, 2015) which indicates that the this concept has not been firmly anchored, as there is no fixed definition of how the "mature" company should be old at what rate it is to grow or what size it is supposed to have. As a rule, the "mature" company is defined only verbally and is characterised by qualitative features. Consequently, the concept itself is largely indefinite and it is not clear where the boundary is between the "young" and the "mature" company. In addition, companies operate in a variety of industries where the characteristics of "maturity" may vary. The issue of the membership of the companies surveyed to the category of mature companies has therefore been decided by the fuzzy logic working with the level of affiliation of the surveyed entity to the interest category. The approach allows us to work with the category of "mature" companies without explicitly expressing the sharp boundaries (values) of criteria which would decide whether or not the enterprise belongs to the category of "mature" companies. Fuzzy logic is an instrument which can effectively solve the absence of sharp boundaries and which also allows incorporating into the research the entities on the borderland to meet the definition characteristics. 
Based on the relevant literature (Jargot, 2006; Dickinson, 2011; Reiners, 2004; Konečný and Zinecker, 2015), the following variables characterising the "mature" company have been selected: assets, leverage, annual growth rate in sales, number of years from incorporation, equity, and growth rate of fixed assets.

Using the knowledge base, we estimate the development of selected financial characteristics in the pre-IPO (it-1) and post-IPO (it+1) period. As we wish to find out if the proceeds of the issue are used in the surveyed sample of companies for the purpose of financing investments, we focus in particular on comparing the growth rate of investments (fixed assets) in the period before and after the IPO. The values of the selected fuzzy variables are available in the Amadeus database. In determining the qualitative and quantitative definition of fulfilment of the individual criteria, we followed the literature, expert estimates and distribution of the quantitative characteristics of specific criteria in the basic set of surveyed companies. We selected the definition area in order to meet the criteria either in absolute or relative terms, with respect to the examined IPO basic set.

In the first stage, we defined a mature company through the assets variable (B20), when we assumed, in line with the literature (Reiners, 2004) that the values for mature companies would tend to oscillate around the upper limit of the observed asset-size range of all companies conducting the IPO in the examined period. The amount of assets in the surveyed sample of companies (basic set) ranges from EUR 443,000 to 267,000,000. Based on the aforementioned assumption that mature companies tend to be "bigger", we determined a fuzzy threshold for these businesses in the range of EUR 75 - 350 million, with the "center" of the interval in the form of the highest membership in group was assumed at EUR 200 million. Alternatively, we also calculated the lower limit at EUR 55 million and 100 million. The definition of the size of the assets of companies which can be considered as mature was carried out at the level of the upper quartile of the total assets of all surveyed companies (basic set) which conducted the IPO in the period 2005 - 2015. The "center" means a value which best represents the value of the specific criterion. The lower and upper limits are the boundaries of admissible values, yet not the most common ones.

In addition, we used the variable of the "age" (U20) of the company in the pre-IPO period. We assumed that it will tend to be longer among mature companies (the assumption is based on the fact that mature companies had to undergo the previous stages of the company's life cycle, which must have taken a certain amount of time). The lower limit was set at 15 years, while the upper limit at 200 years. The centre is then 45 years. The companies in the basic set reach the values from 2 to 124 years.

The gradual depletion of the growth potential of a company was captured by the variable "sales growth" in the pre-IPO period (N20). Such companies achieve positive growth, yet rather lower, single-digit or low two-digit. When determining the parameters of the criterion, we again rely on the assumption of the life cycle stage of the company. Mature companies will have completed a rapid growth phase. However, this growth will be moderate or even negative. In order to define the membership of the companies, we set the lower limit at $0 \%$, the upper limit at 15\%, and the "centre" at 5\%. Alternatively, the values are as follows: lower limit minus 5\%, upper limit 10\%, and centre remains unchanged.

The financial leverage indicator prior to the IPO (D20) was also used to define a mature company. We proceed again from the assumption that if a business has reached the stage of a mature company, in the past, it had to undergo a phase allowing it to accumulate 
resources for its own development. Therefore, in the range of the leverage values, we considered values rather lower, taking into account the successful history of the company. We propose the level of the parameter so that the lower limit of the indicator is 0 , the center at 0.25 and the upper limit at 0.45 , alternatively also at 0.75 .

\section{Research Findings}

Through the defined variables (B20, U20, N20, and D20), we performed an initial query into the knowledge base concerning the return on assets (ROA) in pre-IPO stage (variable L20). The answers provided by the knowledge base concerning the return on assets of a company prior to the IPO were most frequently in the range of 7 to $13 \%$ depending on the range of acceptable thresholds of the input variables (B20, U20, N20, and D20), while only in one case the value of the indicator was negative. The upper limit of $13 \%$ was not exceeded. The resulting values of the reruns on assets prior to the IPO (L20) can be perceived as a confirmation of the suitability of selecting the criteria defining a mature company. The values did not acquire extreme values and are positive. They correspond to the idea of a wellestablished, successful business, however, with already limited growth opportunities, which corresponds to the characteristics of a mature company.

The interval of the return on assets (ROA) values estimated by the knowledge base was further used as part of the knowledge base query concerning the investment growth of a mature company prior to the IPO. Other variables defining the mature company included again the amount of assets prior to the IPO (variable B20), the amount of which is expected to be at the higher limit of the achieved values, the company's age (again rather higher), and the amount of equity in the absolute values (F6). The value of equity ranges from EUR 26,719 to EUR 296,032, with the centre of the interval at the amount of EUR 49,819. In the case mature companies, the amount of equity was expected to reach the upper limit values. Based on the definition, mature companies have successfully passed through the growth phase, thus being large (variable B20) and having sufficient own resources (variable F20).

The answers of the knowledge base concerning the query on the growth rate of investment of mature companies in the pre-IPO period depending on the variability of the input parameters were represented in most cases by positive values ranging from $15 \%$ to $35 \%$. Extreme values then reached negative values in the amount of single-digit per cent or positive values at a level slightly above $50 \%$ (in the entire surveyed set of companies, there were companies which, in the year prior to the IP0, achieved an $80 \%$ investment decrease or, on the other hand, the growth of investments by more than $500 \%$ ). The recorded answers of the knowledge base are consistent with the idea of a moderate investment development for mature companies.

For further queries into the knowledge base concerning the companies' growth and the growth of their investment in the post-IPO phase, we performed expert adjustments of these variables. We eliminated extreme results from the previous queries, i.e. that the investment growth in the pre-IPO phase exceeded 50\% per year, and we also excluded the possibility of a decline in investment. In the long-term, the value of investment growth over $50 \%$ is not consistent with the growth of the company in the mature phase of its development. Slightly negative values seem to be more in line with reality, yet in the longterm they will concern businesses which are already losing their positions. 
We used the defined investment growth in the pre-IPO phase, together with other variables, to query the knowledge base in order to determine whether the companies in the post-IPO phase accelerate their growth (measured by sales) or not. Other variables used in this query included the assets (B20) in the pre-IPO phase and the age of the company (U20). The return on assets (ROA) variable (L20) in the pre-IPO phase is the outcome of the first query. A supplementary criterion included the leverage in the year of conducting the IPO defined by lower values. The answer using the knowledge base determined the growth (Y19) of the defined companies after conducting the IPO in the rage of $29-37 \%$ per year. This considerably exceeds the original assumptions of the company growth in the pre-IPO phase identified in the first query by defining the N20 variable (the values up to $15 \%$ or slightly negative in some variants).

The values related to the growth of corporate sales after conducting the IPO (variable Y19) were used along with other definition features of mature companies estimated on the basis of previous queries into the knowledge base (i.e. the return on assets in the pre-IPO phase (L20) and the investment growth in the pre-IPO phase (020)) to estimate the investment activity of mature companies after the IPO (Z). The response of the knowledge base indicates that companies after conducting the IPO substantially increase their investment. Depending on the setting of the definition parameters of this group of companies, they achieve the investment growth at the level of top tens per cent, yet the most typical situation consists in more than doubling the investment activity. In the whole set of surveyed companies included in the knowledge base, there are also companies that have experienced a decline in investments after the IPO.

Figure 3 shows the sequence of the queries to the knowledge base, including the defining variables.

\section{Discussion and Conclusions}

The research results show that mature companies, as we defined them through fuzzy variables, significantly accelerate their growth in the post-IPO phase. While their sales grow is at a rate of up 15\% per annum before the IPO, the value of this indicator more than doubles in the post-IPO phase. This means that a large number of companies after the IPO significantly increase their investment activity. The finding is especially important for potential investors at the Warsaw Stock Exchange, as academic literature and the results of previous empirical studies suggest that mature companies usually have sufficient equity and access to loan financing. The main motive for the IPO implementation usually includes the efforts to optimise the capital structure, rather than the implementation of new business projects. In the case of these companies, there may also be stronger efforts concerning the IPO timing, i.e. they are listed on the stock exchange only after completing extensive investment policies, being funded, for example, by bank loans. The past growth is supposed to serve as a signal, i.e. to make the issue more attractive in the eye of potential investors (e.g. Chemmanur and Fulghiery, 1999; Pagano et al., 1998; Rajan, 1992).

However, our initial results, which take the form of answers to the knowledge base, show that this is not the case for mature companies entering the Warsaw Stock Exchange. Through the fuzzification of the variables and the subsequent dialogue with the knowledge base, we have succeeded in identifying a group of entities which we define as mature companies and subsequently evaluating their investment activity in the post-IPO phase. The 
proposed methodological approach (the fuzzification of the variables and the subsequent dialogue with the knowledge base) overcomes the shortcomings of ambiguous definition or certain indefiniteness of the boundaries defining the category of "mature" companies.

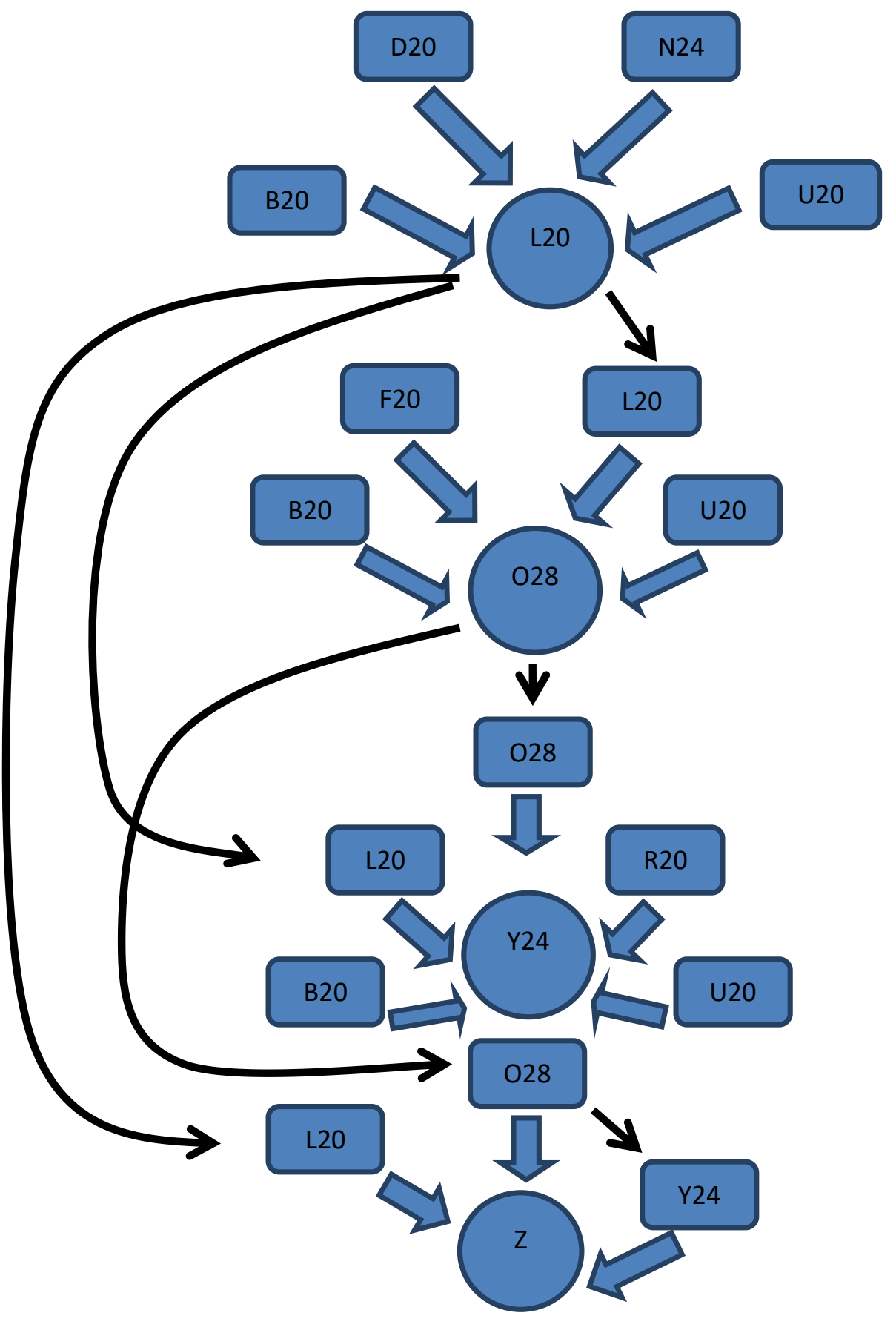

Figure 3. Sequence of queries raised by the knowledge base and using the acquired values for further querying the base

Source: Authors' own research. 
Although the survey methodology used here reveals the very likely motivation of going public, it may also be a source of some limitations. We have the following concerns: research results based on financial data do not represent direct insights from the CFOs; a bias cannot be excluded, because only survey data from decision makers could confirm our conclusions. We analysed financial data of enterprises operating from a part in unfavorable macroeconomic conditions covering financial and economic crisis between 2009 and 2011; this might have affected the financial results and decisions in companies.

In follow-up research, we aim to extend the data experiment to other points in time and involve more countries in Europe with a significant IPO activity.

\section{Acknowledgement}

This paper was supported by the Institute of Economic Research Torun, Poland, and Brno University of Technology, Faculty of Business and Management, Czech Republic (grant number: 2019/1). The title of the project is "Public and Private Equity in CEE countries".

\section{References}

Auret, C., \& Britten, J. (2008). Post-issue operating performance of firms listing on the JSE. Investment Analysts Journal, 37(68), 21-29. DOI: $10.1080 / 10293523.2008 .11082501$.

Bancel, F., \& Mittoo, U. R. (2009). Why Do European Firms Go Public? European Financial Management, 15(4), 844-84. DOI: 10.1111/j.1468-036X.2009.00501.x.

Bikas, E., \& Saponaite, V. (2018). Behavior of the Lithuanian investors at the period of economic growth. Entrepreneurship and Sustainability Issues, 6(1), 44-59. DOI: 10.9770/jesi.2018.6.1(4).

Brau, J., C., \& Kohers, N. (2003). The Choice of IPO versus Takeover: Empirical Evidence. Journal of Business, 76(4), 583-612. DOI: 10.1086/377032.

Brau, J., C., \& Fawcett, S. E. (2006). Initial Public Offerings: An Analysis of Theory and Practice. The Journal of Finance, 61(1), 399-436. DOI: 10.1111/j.1540-6261.2006.00840.x.

Chemmanur, T. J., \& Fulghiery, A. (1999). Theory of the Going-Public Decision. Review of Financial Studies, 12(2), 249-79. DOI: 10.1093/rfs/12.2.249.

Chun, H., \& Smith, S, C. (2002). New Issues in Emerging Markets: Determinants. Effects and Stock Market Performance of IPOs in Korea. Working Paper. Kookmin Bank and George Washington University.

Dickinson, V. (2011). Cash flow patterns as a proxy for firm life-cycle. Accounting Review, 86(6), 1969-1994. DOI: 2308/accr-10130.

Dohnal, M., \& Dohnalova, J. (1992). Food Engineering and Information Non-Intensive Calculi. Journal of Food Engineering, 21(3), 41-60.

Dincer H., Hacioglu U., Tatoglu E. \& Delen D. 2016. A Fuzzy-Hybrid Analytic Model to Assess Investors' Perceptions For Industry Selection. Decision Support Systems, 86(1), 24-34, DOI: 10.1016/j.dss.2016.03.005.

Faff, R., Kwok, W., C., Podolski, E., J., \& Wong, G. (2016). Do corporate policies follow a lifecycle? Journal of Banking \& Finance, 69(2), 95-107. DOI: 10.1016/j.jbankfin.2016.04.009.

Greene, W., C. (2003). Econometric Analysis. 5th Edition. New York: Prentice Hall. 
Hasan, M., M., Hossain, M., Cheung, A., \& Habib, A. (2015). Corporate life cycle and cost of equity capital. Journal of Contemporary Accounting \& Economics, 11(1), 46-60. DOI: 10.1016/j.jcae.2014.12.002.

Helwege, J., Liang, N. (2004). Initial Public Offering in Hot and Cold Markets. Journal of financial and quantitative analysis, 39(3), 541-569.

Ivanová, E. (2017). Barriers to the development of SMEs in the Slovak Republic. Oeconomia Copernicana, 8(2), 255-272. D0I: 10.24136/oc.v8i2.16.

Jargot, A. (2006). Why Polish Companies Go Public: An Analysis of Determinants and Consequences of the Initial Public Offering. Thesis, MSc in Finance \& International Business, Aarhus School of Business.

Kim, W., \& Weisbach, M. (2008). Motivations for public equity offers: An international perspective. Journal of Financial Economics, 87(2), 281-307. DOI: 10.1016/j.jfineco.2006.09.010.

Kisel'áková, D., Horváthová, J., Šofranková, B., \& Šoltés, M. (2015). Analysis of risks and their impact on enterprise performance by creating enterprise risk model. Polish Journal of Management Studies, 11(2): 50-61.

Konečný, Z., \& Zinecker, M. (2015). Using the Boston Matrix by Identification the Corporate Life Cycle. Acta Universitatis Agriculturae et Silviculturae Mendelianae Brunensis, 63(1): 235243.

Konečný, Z., \& Zinecker, M. (2017). Corporate Life Cycle Identification: A Model Based On Relationship Between Return On Equity And Cost Of Equity. Scientific Papers of the University of Pardubice, 3: 67-78.

Lin, C., T., \& Chen, Y., T. (2004). Bid/no-bid decision-making: a fuzzy linguistic approach. International Journal of Project Management, 22(7), 585-593.

Maksimovic, V., \& Pichler, P. (2001). Technological Innovation and Initial Public Offerings. Review of Financial Studies, 14(1), 459-94. DOI: 10.1093/rfs/14.2.459.

Manuylenko, V., V., Loktionova, M., A., Lipchiu, N., V., Sobchenko, N., V., Sadovskaya, T., A. (2018). Options simulation toolkit for strategic evaluation of corporations' financial potential. Entrepreneurship and Sustainability Issues, 6(2), 871-889. DOI: 10.9770/jesi.2018.6.2(27).

Michalak, A. (2016). The cost of capital in the effectiveness assessment of financial management in a company. Oeconomia Copernicana, 7(2), 317-329. DOI: 10.12775/OeC.2016.019.

Meluzín, T., Balcerzak, A., P., Pietrzak, M., B., Zinecker, M., \& Doubravský, K. (2018º). The Impact of Rumours Related to Political and Macroeconomic Uncertainty on IPO Success: Evidence from a Qualitative Model. Transformations in Business \& Economics, 17(2(44)), 148-69.

Meluzín, T., Zinecker, M., Balcerzak, A., P., Doubravský, K., Pietrzak, M., B., \& Dohnal, M. (2018b). The Timing of Initial Public Offerings: Non-Numerical Model Based on Qualitative Trends. Journal of Business Economics and Management, 19(1):63-79. DOI:10.3846/jbem.2018.1539.

Meluzín, T., Zinecker, M., Balcerzak, A. P., \& Pietrzak, M. B. (2018c). Why Companies Do Not Go Public? Key Factors to Consider by IPO Candidates in Poland and Czech Republic. Eastern European Economics, 56(6), 471-503, DOI: 10.1080/00128775.2018.1496795. 
Meluzín, T., Zinecker, M., Lace, N. (2016). Going Public: Key Factors to Consider by IPO Candidates on Emerging Markets of Poland and the Czech Republic. Engineering Economics, 27(4), 392-404. DOI: 10.5755/j01.ee.27.4.14755.

Myers, S. (1984). The Capital Structure Puzzle. The Journal of Finance, 39(3), 575-592. DOI: $10.2307 / 2327916$.

Myers, S., \& Majluf, N. (1984). Corporate Financing and Investment Decisions When Firms Have Information That Investors Do Not Have. Journal of financial economics, 13(2), 187-221. DOI: 10.1016/0304-405X(84)90023-0.

Pagano, M., Panetta, F., \& Zingales, L. (1998). Why Do Companies Go Public? An Empirical Analysis. The Journal of Finance, 53(1), 27-64.

Paeglis, I., \& Veeren. P. (2013). Speed and consequences of venture capitalist post-IPO exit. Journal of Corporate Finance, 22, 104-123. DOI: 10.1016/j.jcorpfin.2013.04.005.

Pastor, L. \& Veronesi, P. (2003). Stock Prices and IPO Waves. NBER Working Papers 9858, National Bureau of Economic Research, Inc.

Peterle, P., \& Berk, A. (2016). IPO Cycles in Central and Eastern Europe: What Factors Drive These Cycles? Czech Journal of Economics and Finance, 66(2):113-39.

Pratt, S., \& Grabowski, R. (2008). Cost of Capital. 3rd ed. Hoboken: Wiley.

Rajan, R., G. (1992). Insiders and Outsiders: The Choice between Informed and Arm's-Length Debt. Journal of Finance, 47: 1367-1400.

Reiners, M. (2004). Finanzierungskosten im Lebenszyklus der Unternehmung. Ein optionspreistheoretischer Ansatz. Hamburg: Verlag Dr. Kovač.

Ritter, J. (1991). The Long-Run Performance of Initial Public Offerings. The Journal of Finance, 46(1), 3-27. DOI: 10.2307/2328687.

Ritter, J., R., \&. Welch, I. (2002). A Review of IPO Activity, Pricing, and Allocations. Journal of Finance, 57(4), 1795-1828. DOI: 10.1111/1540-6261.00478.

Skvarciany, V., Jurevičienė, D., Iljins, J., \& Gaile-Sarkane, E. (2018). Factors influencing a bank's competitive ability: the case of Lithuania and Latvia. Oeconomia Copernicana, 9(1), 7-28. DOI: 10.24136/oc.2018.001.

Sosnowski, T. (2017). Earnings management and the floatation structure: empirical evidence from Polish IPOs. Equilibrium. Quarterly Journal of Economics and Economic Policy, 12(4), 693-709. DOI: 10.24136/eq.v12i4.36.

Sosnowski, T. (2018). Earnings Management in the Private Equity Divestment Process on Warsaw Stock Exchange. Equilibrium. Quarterly Journal of Economics and Economic Policy, 12(4).

Ślusarczyk, B. (2018). Tax incentives as a main factor to attract foreign direct investments in Poland. Administratie si Management Public, 30, 67-81. DOI: 10.24818/amp/2018.3005.

You-Shyang Chen, Ching-Hsue Cheng. (2012). A soft-computing based rough sets classifier for classifying IPO returns in the financial markets. Applied Soft Computing, 12(1): 462-475. DOI: 10.1016/j.asoc.2011.08.023.

Wang, R., C., \& Chuu, S., J. (2004). Group decision-making using a fuzzy linguistic approach for evaluating the flexibility in a manufacturing system. European Journal of Operational Research, 154(3), 563-572. 
Wawryszuk-Misztal, A. (2017). Earnings forecasts errors in prospectuses: evidence from initial public offerings on the Warsaw Stock Exchange. Equilibrium. Quarterly Journal of Economics and Economic Policy, 12(2), 229-243. DOI: 10.24136/eq.v12i2.12.

Wrońska-Bukalska, E., \& Kaźmierska-Jóźwiak, B. (2017). Signaling hypotheses of share repurchase - life cycle approach. The case of Polish listed companies. Equilibrium. Quarterly Journal of Economics and Economic Policy, 12(2), 245-257. DOI: 10.24136/eq.v12i2.13.

Valaskova, K., Kliestik, T., \& Kovacova, M. (2018). Management of financial risks in Slovak enterprises using regression analysis. Oeconomia Copernicana, 9(1), 105-121. DOI: 10.24136/oc.2018.006.

Włodarczyk, B., Szturo, M., Ionescu, G. H., Firoiu, D., Pirvu, R., Badircea, R. (2018). The impact of credit availability on small and medium companies. Entrepreneurship and Sustainability Issues, 5(3), 565-580. DOI: 10.9770/jesi.2018.5.3(12).

Zadeh, L., A. (1965). Fuzzy sets. Information and Control, 8(3), 338-353.

Zimmerman, J. (1987). Fuzzy sets, Decision Making, and Expert Systems. Norwell: Kluwer Academic Publishers. 
Appendix. Fuzzy description of 94 known IPO cases

\begin{tabular}{|c|c|c|c|c|c|c|c|c|c|c|c|c|c|c|c|c|c|c|c|c|c|c|c|c|c|c|}
\hline $\begin{array}{l}\text { A } \\
1 \\
\end{array}$ & $\begin{array}{c}\text { B1 } \\
6 \\
\end{array}$ & $\begin{array}{c}\text { C1 } \\
6 \\
\end{array}$ & 4 & 7 & $\begin{array}{c}\text { F1 } \\
6 \\
\end{array}$ & 6 & & $\begin{array}{l}\mathrm{I} \\
8 \\
\end{array}$ & 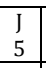 & 2 & $\begin{array}{c}\text { L1 } \\
2 \\
\end{array}$ & $\begin{array}{c}\text { M1 } \\
2 \\
\end{array}$ & $\begin{array}{c}\text { N1 } \\
4 \\
\end{array}$ & $\begin{array}{c}01 \\
3 \\
\end{array}$ & $\begin{array}{l}P 1 \\
6 \\
\end{array}$ & $\begin{array}{c}\text { Q1 } \\
5\end{array}$ & $\begin{array}{c}\text { R1 } \\
4 \\
\end{array}$ & S7 & $\begin{array}{c}\text { T1 } \\
6 \\
\end{array}$ & $\begin{array}{c}\text { U1 } \\
6 \\
\end{array}$ & V6 & W8 & $\begin{array}{c}\mathrm{X} 1 \\
3 \\
\end{array}$ & Y9 & Z10 & $\begin{array}{c}0.5 \\
8 \\
\end{array}$ \\
\hline $\begin{array}{l}\text { A } \\
1 \\
\end{array}$ & $\begin{array}{c}\text { B1 } \\
3\end{array}$ & C1 & $\mathrm{D}$ & E1 & F1 & $\mathrm{G}$ & & 7 & 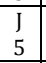 & $\mathrm{K}$ & $\begin{array}{c}\text { L1 } \\
2 \\
\end{array}$ & M8 & N2 & $\begin{array}{c}01 \\
0 \\
\end{array}$ & 1 & $\begin{array}{c}\text { Q1 } \\
6\end{array}$ & $\begin{array}{c}\text { R1 } \\
6 \\
\end{array}$ & S1 & $\begin{array}{c}\text { T1 } \\
1 \\
\end{array}$ & $\begin{array}{c}\text { U1 } \\
4 \\
\end{array}$ & V3 & $\begin{array}{c}\text { W1 } \\
4\end{array}$ & $\begin{array}{c}\mathrm{X} 1 \\
4 \\
\end{array}$ & Y4 & 815 & $\begin{array}{c}0.5 \\
8 \\
\end{array}$ \\
\hline $\begin{array}{l}\text { A } \\
1\end{array}$ & B7 & $\begin{array}{c}\text { C1 } \\
0\end{array}$ & D2 & E6 & $\begin{array}{c}\text { F1 } \\
0\end{array}$ & 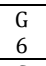 & & 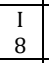 & $\begin{array}{l}\mathrm{J} \\
5 \\
\end{array}$ & $\begin{array}{l}\mathrm{K} \\
2 \\
\end{array}$ & $\begin{array}{c}\text { L1 } \\
8 \\
\end{array}$ & $\begin{array}{c}\text { M1 } \\
5\end{array}$ & $\begin{array}{c}\text { N1 } \\
5\end{array}$ & $\begin{array}{c}01 \\
8 \\
\end{array}$ & P9 & $\begin{array}{c}\text { Q1 } \\
1\end{array}$ & R5 & S7 & $\begin{array}{c}\text { T1 } \\
1 \\
\end{array}$ & U9 & $\begin{array}{c}\text { V1 } \\
5\end{array}$ & $\begin{array}{c}\text { W1 } \\
9\end{array}$ & $\begin{array}{c}\mathrm{X} 1 \\
7\end{array}$ & Y12 & 711 & $\begin{array}{c}0.5 \\
8\end{array}$ \\
\hline $\begin{array}{l}\mathrm{A} \\
1\end{array}$ & B7 & $\begin{array}{c}\text { C1 } \\
0\end{array}$ & & $\begin{array}{c}\text { E1 } \\
7\end{array}$ & F2 & $\begin{array}{l}\text { G } \\
6\end{array}$ & & 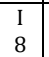 & $\begin{array}{l}\mathrm{J} \\
5\end{array}$ & K & L6 & $\begin{array}{c}\text { M1 } \\
3\end{array}$ & N2 & 02 & P5 & Q8 & $\begin{array}{c}\text { R1 } \\
5\end{array}$ & S1 & $\mathrm{T} 4$ & U7 & V6 & & $\begin{array}{c}\mathrm{X} 1 \\
2\end{array}$ & Y17 & 712 & $\begin{array}{c}0.5 \\
8\end{array}$ \\
\hline $\begin{array}{l}\text { A } \\
1\end{array}$ & B1 & C6 & & E6 & & 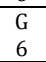 & & $\varepsilon$ & $\begin{array}{l} \\
5\end{array}$ & & L5 & M5 & N1 & 07 & & Q6 & & S2 & $\begin{array}{c}\mathrm{T} 1 \\
2\end{array}$ & U7 & V2 & W5 & X7 & Y6 & Z9 & $\begin{array}{c}0.5 \\
8\end{array}$ \\
\hline $\begin{array}{l}\text { A } \\
1\end{array}$ & $\begin{array}{c}\text { B1 } \\
1\end{array}$ & C9 & $\begin{array}{c}\mathrm{D} \\
0\end{array}$ & E5 & F4 & $\begin{array}{l}G \\
6\end{array}$ & & $\begin{array}{l}\text { I } \\
8\end{array}$ & $\begin{array}{l} \\
5 \\
\end{array}$ & $\begin{array}{l}\mathrm{K} \\
2\end{array}$ & L8 & $\begin{array}{c}\text { M1 } \\
9\end{array}$ & $\begin{array}{c}\text { N1 } \\
6\end{array}$ & $\begin{array}{c}01 \\
5\end{array}$ & $\begin{array}{l}\mathrm{P} 1 \\
4\end{array}$ & $\begin{array}{c}\text { Q1 } \\
1\end{array}$ & $\begin{array}{c}\text { R1 } \\
4\end{array}$ & S2 & $\begin{array}{c}\text { T1 } \\
3\end{array}$ & $\mathrm{U} 4$ & V6 & N4 & X5 & Y17 & 15 & $\begin{array}{c}0.5 \\
8\end{array}$ \\
\hline $\begin{array}{l}\mathrm{A} \\
1\end{array}$ & B2 & C1 & D3 & E6 & F2 & $\begin{array}{l}G \\
6\end{array}$ & & $\begin{array}{l}\text { I } \\
8\end{array}$ & $\begin{array}{l} \\
5\end{array}$ & $\begin{array}{l}\mathrm{K} \\
2\end{array}$ & L7 & M5 & & $\begin{array}{c}01 \\
2\end{array}$ & P1 & Q1 & R3 & S1 & T2 & U4 & & N8 & X5 & 15 & 17 & $\begin{array}{c}0.5 \\
8\end{array}$ \\
\hline $\begin{array}{l}\mathrm{A} \\
2\end{array}$ & B1 & $\begin{array}{c}\mathrm{C} 1 \\
9\end{array}$ & D1 & E1 & 1 & & & $\begin{array}{l}\mathrm{I} \\
1\end{array}$ & $\begin{array}{l}J \\
6\end{array}$ & & L2 & M2 & N7 & 03 & $\begin{array}{l}\mathrm{P} 1 \\
4\end{array}$ & $\begin{array}{c}\text { Q1 } \\
9\end{array}$ & $\begin{array}{c}\text { R1 } \\
6\end{array}$ & & $\begin{array}{c}\text { T1 } \\
3\end{array}$ & U8 & V5 & W9 & $\begin{array}{c}\text { X1 } \\
2\end{array}$ & 12 & 16 & $\begin{array}{c}0.6 \\
4\end{array}$ \\
\hline $\begin{array}{l} \\
2\end{array}$ & $\begin{array}{c}\text { B1 } \\
8\end{array}$ & $\begin{array}{c}\text { C1 } \\
7\end{array}$ & D1 & E5 & $\begin{array}{c}\text { F1 } \\
7\end{array}$ & $\begin{array}{l}G \\
2 \\
\end{array}$ & $\mathrm{H}$ & $\begin{array}{l}\mathrm{I} \\
1\end{array}$ & $\begin{array}{l}J \\
6\end{array}$ & $\begin{array}{l}\mathrm{K} \\
1\end{array}$ & L9 & $\begin{array}{c}\text { M1 } \\
7\end{array}$ & $\begin{array}{c}\mathrm{N} 1 \\
8\end{array}$ & 01 & $\begin{array}{c}\mathrm{P} 1 \\
8 \\
\end{array}$ & $\begin{array}{c}1 \\
8\end{array}$ & $\begin{array}{c}\text { R1 } \\
0\end{array}$ & S4 & $\begin{array}{c}\text { T1 } \\
9\end{array}$ & U9 & & & $\begin{array}{c}\mathrm{X} 1 \\
8\end{array}$ & & & $\begin{array}{c}0.6 \\
4\end{array}$ \\
\hline $\begin{array}{l}\text { A } \\
2 \\
\end{array}$ & $\begin{array}{r}\text { B1 } \\
4 \\
\end{array}$ & $\begin{array}{c}\text { C1 } \\
7 \\
\end{array}$ & D1 & & F1 & C & & 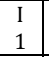 & $\begin{array}{l}\mathrm{J} \\
6\end{array}$ & $\begin{array}{l}\mathrm{K} \\
1 \\
\end{array}$ & L8 & M7 & $\begin{array}{c}\text { N1 } \\
4 \\
\end{array}$ & 03 & $\begin{array}{c}\mathrm{P} 1 \\
4 \\
\end{array}$ & $\begin{array}{c}\text { Q1 } \\
7\end{array}$ & R9 & $\begin{array}{c}\text { S1 } \\
4 \\
\end{array}$ & $\begin{array}{c}\text { T1 } \\
6 \\
\end{array}$ & $\begin{array}{c}\mathrm{U} 1 \\
3 \\
\end{array}$ & & N7 & X6 & & & $\begin{array}{c}0.6 \\
4 \\
\end{array}$ \\
\hline $\begin{array}{l}\mathrm{A} \\
2\end{array}$ & $\begin{array}{c}\text { B1 } \\
9\end{array}$ & $\begin{array}{c}\text { C1 } \\
6\end{array}$ & 6 & & & & & 1 & $\bar{J}$ & $\begin{array}{l}\mathrm{K} \\
1\end{array}$ & L6 & M7 & $\begin{array}{c}\text { N1 } \\
5\end{array}$ & 08 & $\begin{array}{c}\mathrm{P} 1 \\
9\end{array}$ & $\begin{array}{c}\text { Q1 } \\
6\end{array}$ & $\begin{array}{c}\text { R1 } \\
3\end{array}$ & $\begin{array}{c}\text { S1 } \\
2\end{array}$ & $\begin{array}{c}\text { T1 } \\
9\end{array}$ & $\begin{array}{c}\mathrm{U} 1 \\
3\end{array}$ & V8 & & $\begin{array}{c}\text { X1 } \\
6\end{array}$ & & & $\begin{array}{c}0.6 \\
4\end{array}$ \\
\hline $\begin{array}{l}\mathrm{A} \\
2\end{array}$ & B7 & $\begin{array}{c}\text { C1 } \\
1\end{array}$ & $\begin{array}{c}\text { D1 } \\
0\end{array}$ & E6 & F8 & G & & $\begin{array}{l}\mathrm{I} \\
1\end{array}$ & $\mathrm{~J}$ & $\begin{array}{l}\mathrm{K} \\
1\end{array}$ & $\begin{array}{c}\text { L1 } \\
0\end{array}$ & M8 & $\begin{array}{c}\text { N1 } \\
4\end{array}$ & 09 & P7 & $\begin{array}{c}\text { Q1 } \\
2\end{array}$ & R9 & S3 & T7 & $\begin{array}{c}\mathrm{U} 1 \\
6\end{array}$ & & & X8 & Y14 & Z13 & $\begin{array}{c}0.6 \\
4\end{array}$ \\
\hline $\begin{array}{l}\text { A } \\
2\end{array}$ & B8 & C9 & $\begin{array}{c}\mathrm{D} 1 \\
7\end{array}$ & E6 & F5 & $\begin{array}{l}G \\
2 \\
\end{array}$ & & $\begin{array}{l}\mathrm{I} \\
1\end{array}$ & $\mathrm{~J}$ & $\begin{array}{l}\mathrm{K} \\
1 \\
\end{array}$ & L7 & $\begin{array}{c}\text { M1 } \\
0\end{array}$ & $\begin{array}{c}\text { N1 } \\
0\end{array}$ & $\begin{array}{c}01 \\
7\end{array}$ & P7 & Q9 & & S9 & T5 & $\begin{array}{c}\text { U1 } \\
5\end{array}$ & V7 & W6 & X7 & & 16 & $\begin{array}{c}0.6 \\
4\end{array}$ \\
\hline $\begin{array}{l}\text { A } \\
2 \\
\end{array}$ & B9 & 1 & $\begin{array}{r}\mathrm{D} \\
1 \\
\end{array}$ & & & 2 & & $\begin{array}{l}\text { I } \\
1 \\
\end{array}$ & $\begin{array}{l}\mathrm{J} \\
6\end{array}$ & $\begin{array}{l}\mathrm{K} \\
1\end{array}$ & & $\begin{array}{c}\text { M1 } \\
1 \\
\end{array}$ & & $\begin{array}{c}01 \\
4 \\
\end{array}$ & P9 & & & & T7 & U6 & V4 & & $\begin{array}{c}\text { X1 } \\
8 \\
\end{array}$ & & & $\begin{array}{c}0.6 \\
4 \\
\end{array}$ \\
\hline $\begin{array}{l}\mathrm{A} \\
2\end{array}$ & B1 & C1 & $\begin{array}{l}\text { D } \\
6\end{array}$ & & F1 & 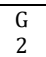 & & $\begin{array}{l}\mathrm{I} \\
1\end{array}$ & \begin{tabular}{|l|}
$J$ \\
6
\end{tabular} & $\mathrm{r}$ & L3 & $\begin{array}{c}\mathrm{M} 2 \\
0\end{array}$ & N8 & $\begin{array}{c}02 \\
0\end{array}$ & P1 & Q1 & & & T1 & U5 & V9 & W1 & X1 & 12 & Z17 & $\begin{array}{c}0.6 \\
4\end{array}$ \\
\hline $\begin{array}{l}\text { A } \\
2 \\
\end{array}$ & B1 & C2 & $\begin{array}{c}\text { D1 } \\
1\end{array}$ & & F1 & G & & 1 & $\begin{array}{l}\mathrm{J} \\
6 \\
\end{array}$ & $\mathrm{r}$ & $\begin{array}{c}\text { L1 } \\
8 \\
\end{array}$ & $\begin{array}{c}\text { M1 } \\
8\end{array}$ & & $\begin{array}{c}01 \\
9 \\
\end{array}$ & P2 & Q2 & R8 & & T3 & $\mathrm{U} 4$ & & & $\begin{array}{c}\mathrm{X} 1 \\
0 \\
\end{array}$ & & & $\begin{array}{c}0.6 \\
4 \\
\end{array}$ \\
\hline $\begin{array}{l}\text { A } \\
3\end{array}$ & $\begin{array}{c}\text { B1 } \\
2\end{array}$ & $\begin{array}{c}\text { C1 } \\
7\end{array}$ & $\begin{array}{c}\text { D1 } \\
6\end{array}$ & & $\begin{array}{c}\text { F1 } \\
0\end{array}$ & $\mathrm{G}$ & & 1 & $\mathrm{~J}$ & $\begin{array}{l}\mathrm{K} \\
4\end{array}$ & & $\begin{array}{c}\text { M1 } \\
8\end{array}$ & & $\begin{array}{c}01 \\
8\end{array}$ & $\begin{array}{c}\mathrm{P} 1 \\
6\end{array}$ & & & & & $\begin{array}{c}\text { U1 } \\
4\end{array}$ & & & $\mathrm{X} 1$ & & & $\begin{array}{c}0.7 \\
0\end{array}$ \\
\hline $\begin{array}{l}\text { A } \\
3 \\
\end{array}$ & $\begin{array}{c}\text { B1 } \\
6\end{array}$ & $\begin{array}{c}\mathrm{C} 1 \\
\end{array}$ & D9 & E6 & & & & 2 & $\mathrm{~J}$ & $\begin{array}{l}\mathrm{K} \\
4 \\
\end{array}$ & L1 & M8 & $\mathrm{N}$ & $\begin{array}{c}01 \\
9 \\
\end{array}$ & 1 & $\begin{array}{c}\text { Q1 } \\
8\end{array}$ & R9 & S2 & $\begin{array}{c}\text { T1 } \\
9 \\
\end{array}$ & $\begin{array}{c}\mathrm{U} 1 \\
4 \\
\end{array}$ & & W8 & X7 & & 75 & $\begin{array}{c}0.7 \\
0 \\
\end{array}$ \\
\hline $\begin{array}{l}\mathrm{A} \\
3 \\
\end{array}$ & B8 & C1 & $\begin{array}{c}\text { D1 } \\
9\end{array}$ & $\begin{array}{r}\mathrm{E} 1 \\
5\end{array}$ & F4 & & 1 & $\frac{1}{2}$ & $\mathrm{~J}$ & $\begin{array}{l}\mathrm{K} \\
4\end{array}$ & L6 & $\begin{array}{c}\text { M1 } \\
1\end{array}$ & $\begin{array}{r}\mathrm{N} \\
3 \\
\end{array}$ & $\begin{array}{c}01 \\
9\end{array}$ & P8 & & & & T7 & U6 & V8 & & X4 & Y7 & $\mathrm{Z} 4$ & $\begin{array}{c}0.7 \\
0\end{array}$ \\
\hline $\begin{array}{l}\mathrm{A} \\
3\end{array}$ & $\begin{array}{c}\text { B1 } \\
2\end{array}$ & $\bar{C}$ & D9 & & & & & 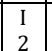 & $\begin{array}{l}\mathrm{J} \\
7\end{array}$ & $\bar{r}$ & & $\mathrm{M}$ & & $\begin{array}{c}01 \\
4\end{array}$ & & & R8 & & & & & & & Y3 & $\mathrm{Z} 10$ & $\begin{array}{c}0.7 \\
0\end{array}$ \\
\hline $\begin{array}{l}\mathrm{A} \\
3\end{array}$ & $\begin{array}{c}\text { B1 } \\
0\end{array}$ & 2 & D9 & E4 & & & & 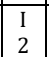 & 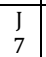 & & & & & 08 & & & R5 & S6 & & $\begin{array}{c}\text { U1 } \\
9\end{array}$ & & & & Y3 & Z10 & $\begin{array}{c}0.7 \\
0\end{array}$ \\
\hline $\begin{array}{l}\text { A } \\
3\end{array}$ & $\begin{array}{c}\text { B1 } \\
3 \\
\end{array}$ & & & & & & & 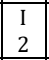 & 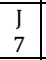 & & & & & 09 & & & R8 & & & & & & & & Z17 & $\begin{array}{c}0.7 \\
0\end{array}$ \\
\hline $\begin{array}{l}\text { A } \\
3\end{array}$ & B8 & $\begin{array}{c}\mathrm{C} 1 \\
2\end{array}$ & $\begin{array}{c}\text { D1 } \\
0\end{array}$ & E9 & F9 & 7 & & $\frac{1}{2}$ & $\mathrm{~J}$ & & & & & & & & R6 & S8 & & $\begin{array}{c}\mathrm{U} 1 \\
1\end{array}$ & & & & & Z8 & $\begin{array}{c}0.7 \\
0\end{array}$ \\
\hline $\begin{array}{l}\text { A } \\
3 \\
\end{array}$ & B3 & C6 & $\begin{array}{c}\text { D1 } \\
8 \\
\end{array}$ & & & ( & & . & $\begin{array}{l}\mathrm{J} \\
7 \\
\end{array}$ & & & & & $\begin{array}{c}01 \\
6 \\
\end{array}$ & & & & & & $\mathrm{U} 4$ & & & X4 & & & $\begin{array}{c}0.7 \\
0 \\
\end{array}$ \\
\hline $\begin{array}{l}\text { A } \\
3\end{array}$ & $\begin{array}{c}\text { B1 } \\
1\end{array}$ & & $\begin{array}{c}\text { D1 } \\
4\end{array}$ & E7 & & & & & & & & $\begin{array}{c}\text { M1 } \\
2\end{array}$ & & & & & & S & & $\begin{array}{c}\text { U1 } \\
8\end{array}$ & & & & & & $\begin{array}{c}0.7 \\
0\end{array}$ \\
\hline $\begin{array}{l}\text { A } \\
3 \\
\end{array}$ & $\begin{array}{c}\text { B1 } \\
0\end{array}$ & $\begin{array}{c}C \\
5\end{array}$ & $\begin{array}{c}\text { D1 } \\
7 \\
\end{array}$ & & $\mathrm{~F}$ & & & $\frac{1}{2}$ & $\mathrm{~J}$ & & & $\begin{array}{c}\text { M1 } \\
2\end{array}$ & & $\begin{array}{c}01 \\
6\end{array}$ & & & & & & $\begin{array}{c}\text { U1 } \\
3\end{array}$ & & & & & & $\begin{array}{c}0.7 \\
0\end{array}$ \\
\hline $\begin{array}{l}\mathrm{A} \\
3\end{array}$ & $\begin{array}{c}\text { B1 } \\
8\end{array}$ & C1 & D9 & E1 & & & & & $\begin{array}{l} \\
7\end{array}$ & & & M2 & & $\begin{array}{c}01 \\
5\end{array}$ & & Q5 & $P Q$ & S3 & & U1 & & & & & 75 & $\begin{array}{c}0.7 \\
0\end{array}$ \\
\hline $\begin{array}{l}\mathrm{A} \\
3 \\
\end{array}$ & $\begin{array}{r} \\
4 \\
\end{array}$ & & D5 & E9 & & & & 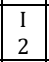 & $\begin{array}{l} \\
7 \\
\end{array}$ & & L9 & M6 & & 07 & & & B7 & & & & & & X8 & Y3 & Z5 & $\begin{array}{c}0.7 \\
0.7\end{array}$ \\
\hline $\begin{array}{l}\text { A } \\
3\end{array}$ & $\begin{array}{c}\text { B1 } \\
0\end{array}$ & & D6 & E1 & & & & $\frac{1}{2}$ & $\frac{J}{7}$ & & & M8 & & & & & 86 & S1 & & U7 & & & & Y4 & Z7 & $\begin{array}{c}0.7 \\
0\end{array}$ \\
\hline $\begin{array}{l}\text { A } \\
3\end{array}$ & B5 & C8 & $\begin{array}{c}\text { D1 } \\
1\end{array}$ & & F6 & 9 & $\mathrm{H}$ & 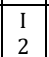 & $\begin{array}{l}\mathrm{J} \\
7\end{array}$ & $\begin{array}{l}\mathrm{K} \\
4\end{array}$ & & & & 07 & P7 & Q9 & $\mathrm{R} \epsilon$ & S & T8 & & & & & Y8 & Z12 & $\begin{array}{c}0.7 \\
0\end{array}$ \\
\hline $\begin{array}{l}\text { A } \\
3\end{array}$ & B6 & C7 & $\begin{array}{c}\text { D1 } \\
5\end{array}$ & E1 & F5 & 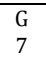 & & 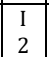 & J & 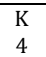 & & & & & P7 & Q9 & $\mathrm{R} 9$ & S2 & T7 & & & & & Y7 & Z6 & $\begin{array}{c}0.7 \\
0\end{array}$ \\
\hline $\begin{array}{l}\text { A } \\
3\end{array}$ & B5 & C6 & $\begin{array}{c}\text { D1 } \\
5\end{array}$ & $\mathrm{E}$ & $\mathrm{F}$ & 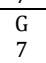 & $\mathrm{H}$ & $\frac{1}{2}$ & $\mathrm{~J}$ & $\mathrm{H}$ & & & & 0 & & & N & & & U5 & & & X6 & & 1 & $\begin{array}{c}0.7 \\
0\end{array}$ \\
\hline $\begin{array}{l}\text { A } \\
3\end{array}$ & $\begin{array}{c}\text { B1 } \\
0\end{array}$ & C & $\begin{array}{c}\text { D1 } \\
5\end{array}$ & $\begin{array}{l}E \\
5\end{array}$ & $F$ & & $\mathrm{H}$ & 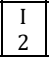 & 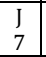 & 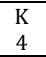 & $\mathrm{L}$ & M4 & & & & & & & & $\begin{array}{c}\text { U1 } \\
8\end{array}$ & V & $\sqrt{ } 4$ & X3 & & & $\begin{array}{c}0.7 \\
0\end{array}$ \\
\hline $\begin{array}{l}\text { A } \\
3 \\
\end{array}$ & B4 & C6 & D2 & E8 & F7 & & $\mathrm{H}$ & I & $\mathrm{J}$ & & & & & $\begin{array}{c}01 \\
7 \\
\end{array}$ & & & R2 & & & U9 & & & & & & $\begin{array}{c}0.7 \\
0 \\
\end{array}$ \\
\hline $\begin{array}{l}\text { A } \\
3\end{array}$ & & $\begin{array}{c}\mathrm{C} 1 \\
0\end{array}$ & & & & & $\mathrm{H}$ & $\begin{array}{l} \\
2\end{array}$ & $\begin{array}{l}\mathrm{J} \\
7\end{array}$ & $\begin{array}{l}K \\
4\end{array}$ & & M9 & $\mathrm{N}$ & 06 & & $\begin{array}{c}\text { Q1 } \\
0\end{array}$ & & & & $\begin{array}{c}\text { U1 } \\
7\end{array}$ & V3 & & $\begin{array}{c}\mathrm{X} 1 \\
9\end{array}$ & & & $\begin{array}{c}0.7 \\
0\end{array}$ \\
\hline $\begin{array}{l}\text { A } \\
3\end{array}$ & B2 & C3 & $\begin{array}{c}\text { D1 } \\
5\end{array}$ & E9 & F2 & 7 & $\begin{array}{l}\mathrm{H} \\
7\end{array}$ & $\begin{array}{l}\text { I } \\
2\end{array}$ & $\begin{array}{l}\mathrm{J} \\
7\end{array}$ & $\begin{array}{l}\mathrm{K} \\
4 \\
\end{array}$ & & & & & & Q4 & R7 & נo & $1 T$ & U6 & & & $\mathrm{X} 9$ & & 214 & $\begin{array}{c}0.7 \\
0\end{array}$ \\
\hline $\begin{array}{l}\text { A } \\
3 \\
\end{array}$ & B6 & C7 & $\begin{array}{c}\text { D1 } \\
5\end{array}$ & & F5 & $\begin{array}{l}\mathrm{G} \\
7 \\
\end{array}$ & $\begin{array}{l}\mathrm{H} \\
7\end{array}$ & $\begin{array}{l}I \\
2 \\
\end{array}$ & $\begin{array}{l} \\
7 \\
\end{array}$ & $\begin{array}{l}\mathrm{K} \\
4 \\
\end{array}$ & L5 & IIS & & 03 & 84 & Q8 & & & 15 & & & W3 & & Y3 & $\mathrm{Z} 2$ & $\begin{array}{c}0.7 \\
0\end{array}$ \\
\hline $\begin{array}{l}\text { A } \\
3 \\
\end{array}$ & B2 & C5 & D7 & E1 & F3 & $\begin{array}{l}\mathrm{G} \\
7 \\
\end{array}$ & $\begin{array}{l}\mathrm{H} \\
7 \\
\end{array}$ & $\begin{array}{l}I \\
2 \\
\end{array}$ & $\begin{array}{l} \\
7 \\
\end{array}$ & $\begin{array}{l}\mathrm{K} \\
4 \\
\end{array}$ & L4 & NIJ & N5 & & PI & Q5 & & & $\mathrm{T} 1$ & $\begin{array}{c}\text { U1 } \\
8\end{array}$ & V9 & $\begin{array}{c}\text { W1 } \\
2\end{array}$ & & Y2 & $\mathrm{Z} 2$ & $\begin{array}{c}0.7 \\
0\end{array}$ \\
\hline $\bar{A}$ & B3 & C2 & D3 & & F4 & $\begin{array}{l}\text { G } \\
7\end{array}$ & $\mathrm{H}$ & $\begin{array}{l}\mathrm{I} \\
2\end{array}$ & $\begin{array}{l}J \\
7\end{array}$ & $\begin{array}{l}\mathrm{K} \\
4\end{array}$ & & & & & P4 & Q2 & R1 & & T5 & U8 & & W9 & X5 & Y5 & Z14 & $\begin{array}{c}0.7 \\
0\end{array}$ \\
\hline
\end{tabular}




\begin{tabular}{|c|c|c|c|c|c|c|c|c|c|c|c|c|c|c|c|c|c|c|c|c|c|c|c|c|c|c|}
\hline $\begin{array}{l}A \\
3\end{array}$ & $\begin{array}{c}\mathrm{B} 1 \\
2 \\
\end{array}$ & $\begin{array}{c}\text { C1 } \\
8 \\
\end{array}$ & $\begin{array}{c}\text { D1 } \\
6\end{array}$ & E9 & $\begin{array}{c}\mathrm{F} 1 \\
1 \\
\end{array}$ & $\begin{array}{l}\text { G } \\
7\end{array}$ & & $\begin{array}{l}\mathrm{I} \\
2 \\
\end{array}$ & $\begin{array}{l}J \\
7 \\
\end{array}$ & $\begin{array}{l}\mathrm{K} \\
4 \\
\end{array}$ & L7 & M8 & $\begin{array}{c}\mathrm{N} 1 \\
2 \\
\end{array}$ & $\begin{array}{c}01 \\
6 \\
\end{array}$ & $\begin{array}{c}\text { P1 } \\
3 \\
\end{array}$ & $\begin{array}{c}\text { Q1 } \\
7 \\
\end{array}$ & $\begin{array}{c}\mathrm{R} 1 \\
7\end{array}$ & S9 & $\begin{array}{c}\text { T1 } \\
1 \\
\end{array}$ & U8 & V4 & W7 & X9 & Y6 & Z12 & $\begin{array}{c}0.7 \\
0\end{array}$ \\
\hline A & B9 & C3 & D2 & E3 & $\begin{array}{c}\mathrm{F} 1 \\
2\end{array}$ & G & $\mathrm{H}$ & $\begin{array}{l}\mathrm{I} \\
2\end{array}$ & $\begin{array}{l}\mathrm{J} \\
7\end{array}$ & $\begin{array}{l}\mathrm{K} \\
4 \\
\end{array}$ & L5 & M3 & N6 & $\begin{array}{c}01 \\
4\end{array}$ & P8 & Q3 & R3 & S4 & $\begin{array}{c}\mathrm{T} 1 \\
1\end{array}$ & $\begin{array}{c}\text { U1 } \\
4\end{array}$ & $\begin{array}{c}\text { V1 } \\
7 \\
\end{array}$ & W4 & X3 & Y4 & Z3 & $\begin{array}{c}0.7 \\
0\end{array}$ \\
\hline $\begin{array}{l}\mathrm{A} \\
3 \\
\end{array}$ & B4 & C5 & $\begin{array}{c}\text { D1 } \\
9 \\
\end{array}$ & E9 & F3 & $\begin{array}{l}G \\
7\end{array}$ & $\mathrm{H}$ & $\begin{array}{l} \\
2 \\
\end{array}$ & $\begin{array}{l}J \\
7 \\
\end{array}$ & $\begin{array}{l}\mathrm{K} \\
4 \\
\end{array}$ & L1 & M1 & N3 & $\begin{array}{c}01 \\
1 \\
\end{array}$ & P4 & Q4 & R4 & S7 & T5 & $\begin{array}{c}\text { U1 } \\
8 \\
\end{array}$ & $\begin{array}{c}\text { V1 } \\
7\end{array}$ & W2 & $\mathrm{X} 2$ & Y1 & $\mathrm{Z} 2$ & $\begin{array}{c}0.7 \\
0\end{array}$ \\
\hline $\begin{array}{l}\mathrm{A} \\
3\end{array}$ & $\begin{array}{c}\text { B1 } \\
9\end{array}$ & $\begin{array}{c}\text { C1 } \\
6\end{array}$ & $\overline{\mathrm{D}}$ & E1 & $\begin{array}{c}\text { F1 } \\
9\end{array}$ & $\begin{array}{l}G \\
7\end{array}$ & $\mathrm{~F}$ & $\begin{array}{l}\text { I } \\
2\end{array}$ & $\begin{array}{l}J \\
7\end{array}$ & $\begin{array}{l}\mathrm{K} \\
4\end{array}$ & L2 & M2 & $\mathrm{N} 2$ & $\begin{array}{c}01 \\
2\end{array}$ & $\begin{array}{c}\mathrm{P} 1 \\
9\end{array}$ & $\begin{array}{c}\text { Q1 } \\
4\end{array}$ & $\begin{array}{c}\text { R1 } \\
7\end{array}$ & S4 & $\begin{array}{c}\text { T1 } \\
8\end{array}$ & $\begin{array}{c}\text { U1 } \\
4\end{array}$ & V3 & W3 & X3 & Y6 & Z8 & $\begin{array}{c}0.7 \\
0\end{array}$ \\
\hline $\begin{array}{l}\mathrm{A} \\
4\end{array}$ & $\begin{array}{c}1 \\
8\end{array}$ & $\begin{array}{c}\text { C1 } \\
9\end{array}$ & $\mathrm{D}$ & $\begin{array}{c}\text { E1 } \\
5\end{array}$ & F1 & G & $\bar{H}$ & $\begin{array}{l}\mathrm{I} \\
3\end{array}$ & $\begin{array}{l}J \\
3\end{array}$ & $\begin{array}{l}\mathrm{K} \\
7\end{array}$ & $\begin{array}{c}\text { L1 } \\
7\end{array}$ & $\begin{array}{c}\text { M1 } \\
9\end{array}$ & $\begin{array}{c}\text { N1 } \\
0\end{array}$ & 06 & $\begin{array}{c}\text { P1 } \\
7\end{array}$ & $\begin{array}{c}\text { Q1 } \\
9\end{array}$ & $\begin{array}{c}\mathrm{R} 1 \\
6\end{array}$ & $\begin{array}{c}\text { S1 } \\
2\end{array}$ & $\begin{array}{c}\text { T1 } \\
7\end{array}$ & $\begin{array}{c}\mathrm{U} 1 \\
1\end{array}$ & V5 & $\begin{array}{c}\text { W2 } \\
0\end{array}$ & $\begin{array}{c}\text { X2 } \\
0\end{array}$ & Y9 & Z14 & $\begin{array}{c}0.7 \\
6\end{array}$ \\
\hline $\begin{array}{l}\text { A } \\
4\end{array}$ & $\begin{array}{c}\text { B1 } \\
8\end{array}$ & $\begin{array}{c}\mathrm{C} 1 \\
8\end{array}$ & $\begin{array}{c}\text { D1 } \\
6\end{array}$ & $\begin{array}{c}\text { E1 } \\
1\end{array}$ & $\begin{array}{c}\text { F1 } \\
7\end{array}$ & $\bar{G}$ & $\bar{H}$ & $\begin{array}{l}I \\
3\end{array}$ & $\begin{array}{l}J \\
3\end{array}$ & $\begin{array}{l}\mathrm{K} \\
7\end{array}$ & L9 & $\begin{array}{c}\text { M1 } \\
1\end{array}$ & N6 & 03 & $\begin{array}{c}\text { P1 } \\
7\end{array}$ & $\begin{array}{c}\text { Q1 } \\
8\end{array}$ & $\begin{array}{c}\text { R1 } \\
4\end{array}$ & $\begin{array}{c}\text { S1 } \\
0\end{array}$ & $\begin{array}{c}\text { T1 } \\
7\end{array}$ & $\begin{array}{c}\text { U1 } \\
8\end{array}$ & V6 & $\begin{array}{c}\text { W1 } \\
2\end{array}$ & $\begin{array}{c}\mathrm{X} 1 \\
5\end{array}$ & Y4 & Z13 & $\begin{array}{c}0.7 \\
6\end{array}$ \\
\hline $\begin{array}{l}\text { A } \\
4\end{array}$ & $\begin{array}{c}\text { B1 } \\
6\end{array}$ & $\begin{array}{c}\text { C1 } \\
8\end{array}$ & D9 & $\begin{array}{c}\text { E1 } \\
1\end{array}$ & $\begin{array}{c}\text { F1 } \\
7\end{array}$ & $\begin{array}{l}\mathrm{G} \\
8\end{array}$ & $\mathrm{H}$ & $\begin{array}{l}\text { I } \\
3\end{array}$ & $\begin{array}{l}J \\
3\end{array}$ & $\begin{array}{l}\mathrm{K} \\
7\end{array}$ & $\begin{array}{c}\text { L1 } \\
3\end{array}$ & $\begin{array}{c}\text { M1 } \\
3\end{array}$ & N3 & 09 & $\begin{array}{c}\text { P1 } \\
6\end{array}$ & $\begin{array}{c}\text { Q1 } \\
7\end{array}$ & R5 & $\begin{array}{c}\text { S1 } \\
3\end{array}$ & $\begin{array}{c}\text { T1 } \\
7\end{array}$ & U2 & $\begin{array}{c}\text { V1 } \\
6\end{array}$ & W6 & X5 & Y11 & Z14 & $\begin{array}{c}0.7 \\
6\end{array}$ \\
\hline $\begin{array}{l}\text { A } \\
4\end{array}$ & B4 & C3 & D1 & E6 & F8 & $\begin{array}{l}G \\
8\end{array}$ & $\mathrm{H}$ & $\begin{array}{l}\text { I } \\
3\end{array}$ & $\begin{array}{l} \\
3 \\
3\end{array}$ & $\begin{array}{l}\mathrm{K} \\
7\end{array}$ & L2 & M2 & $\begin{array}{c}\mathrm{N} 1 \\
5\end{array}$ & $\begin{array}{c}01 \\
8\end{array}$ & P3 & Q4 & R7 & S9 & $\mathrm{T} 4$ & $\begin{array}{c}\text { U1 } \\
6\end{array}$ & $\begin{array}{c}\text { V1 } \\
4\end{array}$ & W1 & X2 & Y17 & Z18 & $\begin{array}{c}0.7 \\
6\end{array}$ \\
\hline $\begin{array}{l}\text { A } \\
4\end{array}$ & $\begin{array}{c}\text { B1 } \\
2\end{array}$ & $\begin{array}{c}\text { C1 } \\
7\end{array}$ & $\begin{array}{c}\mathrm{D} 2 \\
0\end{array}$ & E8 & F6 & $\begin{array}{l}G \\
8\end{array}$ & $\mathrm{H}$ & $\begin{array}{l}\mathrm{I} \\
3\end{array}$ & $\begin{array}{l}J \\
3 \\
\end{array}$ & $\begin{array}{l}\mathrm{K} \\
7\end{array}$ & L1 & $\begin{array}{c}\text { M1 } \\
9\end{array}$ & N7 & $\begin{array}{c}01 \\
3 \\
3\end{array}$ & $\begin{array}{c}\text { P1 } \\
3\end{array}$ & $\begin{array}{c}\text { Q1 } \\
7\end{array}$ & $\begin{array}{c}\text { R1 } \\
6\end{array}$ & S7 & $\begin{array}{c}\text { T1 } \\
1\end{array}$ & $\begin{array}{c}\text { U1 } \\
8\end{array}$ & V5 & $\begin{array}{c}\text { W1 } \\
6\end{array}$ & $\mathrm{X} 1$ & Y3 & Z14 & $\begin{array}{c}0.7 \\
6\end{array}$ \\
\hline $\begin{array}{l}\mathrm{A} \\
4 \\
\end{array}$ & $\begin{array}{c}\text { B1 } \\
7\end{array}$ & $\begin{array}{c}\text { C1 } \\
6\end{array}$ & $\begin{array}{c}\text { D1 } \\
9\end{array}$ & E7 & $\begin{array}{c}\text { F1 } \\
4 \\
\end{array}$ & G & $\mathrm{H}$ & $\begin{array}{l}\text { I } \\
3\end{array}$ & $\begin{array}{l}\mathrm{J} \\
3\end{array}$ & $\begin{array}{l}\mathrm{K} \\
7 \\
\end{array}$ & L4 & M5 & N8 & 09 & $\begin{array}{c}\text { P1 } \\
6\end{array}$ & $\begin{array}{c}\text { Q1 } \\
5\end{array}$ & $\begin{array}{c}\text { R2 } \\
0\end{array}$ & S6 & $\begin{array}{c}\text { T1 } \\
0\end{array}$ & $\begin{array}{c}\mathrm{U} 1 \\
0\end{array}$ & V1 & W4 & X7 & Y14 & $\mathrm{Z} 4$ & $\begin{array}{c}0.7 \\
6\end{array}$ \\
\hline $\begin{array}{l}\text { A } \\
4 \\
\end{array}$ & B5 & C7 & $\begin{array}{c}\text { D1 } \\
2 \\
\end{array}$ & $\begin{array}{c}\text { E1 } \\
2 \\
\end{array}$ & F5 & $\begin{array}{l}G \\
8 \\
\end{array}$ & $\mathrm{H}$ & $\begin{array}{l}\text { I } \\
3 \\
\end{array}$ & $\begin{array}{l} \\
3 \\
\end{array}$ & $\begin{array}{l}\mathrm{K} \\
7 \\
\end{array}$ & & $\begin{array}{c}\text { M1 } \\
5\end{array}$ & $\begin{array}{c}\text { N1 } \\
7\end{array}$ & $\begin{array}{c}01 \\
6 \\
\end{array}$ & P7 & Q9 & $\begin{array}{c}\text { R1 } \\
3\end{array}$ & S9 & T6 & U7 & V7 & $\begin{array}{c}\text { W1 } \\
5\end{array}$ & $\begin{array}{c}\mathrm{X} 1 \\
6\end{array}$ & Y11 & Z15 & $\begin{array}{c}0.7 \\
6 \\
\end{array}$ \\
\hline $\begin{array}{l}\text { A } \\
4\end{array}$ & B5 & C4 & D3 & $\begin{array}{c}\text { E1 } \\
5\end{array}$ & F5 & $\begin{array}{l}G \\
8\end{array}$ & $\begin{array}{l}\mathrm{H} \\
5\end{array}$ & $\begin{array}{l}\text { I } \\
3\end{array}$ & $\begin{array}{l}J \\
3\end{array}$ & $\begin{array}{l}\mathrm{K} \\
7\end{array}$ & $\begin{array}{c}\text { L1 } \\
3\end{array}$ & M8 & N3 & 06 & P3 & Q4 & R7 & $\begin{array}{c}\text { S1 } \\
1\end{array}$ & $\mathrm{~T} 4$ & U2 & $\begin{array}{c}\text { V1 } \\
4\end{array}$ & $\begin{array}{c}\mathrm{W} 1 \\
0\end{array}$ & X6 & Y11 & Z9 & $\begin{array}{c}0.7 \\
6\end{array}$ \\
\hline $\begin{array}{l}\text { A } \\
4 \\
\end{array}$ & B3 & C4 & $\begin{array}{c}\mathrm{D} 1 \\
2 \\
\end{array}$ & $\begin{array}{c}\text { E1 } \\
2\end{array}$ & F3 & $\begin{array}{l}G \\
8 \\
\end{array}$ & $\begin{array}{l}\mathrm{H} \\
5 \\
\end{array}$ & \begin{tabular}{l|}
$\mathrm{I}$ \\
3 \\
\end{tabular} & $\begin{array}{l}J \\
3 \\
\end{array}$ & $\begin{array}{l}K \\
7 \\
\end{array}$ & $\begin{array}{c}\text { L1 } \\
6\end{array}$ & $\begin{array}{c}\text { M1 } \\
6\end{array}$ & N3 & $\begin{array}{c}01 \\
5\end{array}$ & P3 & Q3 & R8 & $\begin{array}{c}\text { S1 } \\
5\end{array}$ & T3 & U9 & $\begin{array}{c}\text { V1 } \\
3\end{array}$ & $\begin{array}{c}\text { W1 } \\
2\end{array}$ & $\begin{array}{c}\mathrm{X} 1 \\
0\end{array}$ & Y16 & Z5 & $\begin{array}{c}0.7 \\
6\end{array}$ \\
\hline $\begin{array}{l}\text { A } \\
4\end{array}$ & B6 & C4 & D6 & $\begin{array}{c}\text { E1 } \\
3\end{array}$ & F7 & $\begin{array}{l}G \\
8\end{array}$ & $\begin{array}{l}\mathrm{H} \\
5\end{array}$ & \begin{tabular}{l|}
$\mathrm{I}$ \\
3
\end{tabular} & $\begin{array}{l} \\
3 \\
3\end{array}$ & $\begin{array}{l}\mathrm{K} \\
7\end{array}$ & L1 & $\begin{array}{c}\text { M1 } \\
6\end{array}$ & $\mathrm{~N} 4$ & $\begin{array}{c}01 \\
3\end{array}$ & P5 & Q3 & R2 & $\begin{array}{c}\text { S1 } \\
0\end{array}$ & T7 & $\begin{array}{c}\text { U1 } \\
2\end{array}$ & $\begin{array}{c}\text { V1 } \\
8\end{array}$ & $\begin{array}{c}\text { W1 } \\
6\end{array}$ & $\begin{array}{c}\mathrm{X} 1 \\
3\end{array}$ & Y5 & Z7 & $\begin{array}{c}0.7 \\
6\end{array}$ \\
\hline $\begin{array}{l}\text { A } \\
4\end{array}$ & B1 & C2 & D6 & E6 & F1 & $\begin{array}{l}G \\
8\end{array}$ & $\mathrm{H}$ & $\begin{array}{l}\text { I } \\
3\end{array}$ & $\begin{array}{l}J \\
3\end{array}$ & $\begin{array}{l}\mathrm{K} \\
7\end{array}$ & $\begin{array}{c}\text { L1 } \\
5\end{array}$ & $\begin{array}{c}\text { M1 } \\
1\end{array}$ & N5 & $\begin{array}{c}01 \\
5\end{array}$ & P1 & Q2 & R3 & $\begin{array}{c}\text { S1 } \\
0\end{array}$ & T1 & U9 & $\begin{array}{c}\text { V1 } \\
8\end{array}$ & W5 & X3 & Y1 & $\mathrm{Z} 2$ & $\begin{array}{c}0.7 \\
6\end{array}$ \\
\hline $\begin{array}{l}\mathrm{A} \\
4\end{array}$ & B3 & C4 & $\begin{array}{c}\text { D1 } \\
2\end{array}$ & $\begin{array}{c}\text { E1 } \\
7\end{array}$ & F3 & $\begin{array}{l}G \\
8\end{array}$ & $\mathrm{H}$ & $\begin{array}{l}\text { I } \\
3\end{array}$ & $\begin{array}{l}J \\
3\end{array}$ & $\begin{array}{l}\mathrm{K} \\
7\end{array}$ & L7 & M5 & $\mathrm{N} 2$ & 05 & P2 & Q3 & $\begin{array}{c}\text { R1 } \\
0\end{array}$ & $\begin{array}{c}\text { S1 } \\
7\end{array}$ & T2 & U2 & $\begin{array}{c}\text { V1 } \\
0\end{array}$ & W7 & X7 & Y5 & Z6 & $\begin{array}{c}0.7 \\
6\end{array}$ \\
\hline $\begin{array}{l}\text { A } \\
5\end{array}$ & $\begin{array}{c}\text { B2 } \\
0\end{array}$ & $\begin{array}{c}\text { C1 } \\
9\end{array}$ & $\begin{array}{c}\text { D1 } \\
5\end{array}$ & $\begin{array}{c}\text { E1 } \\
4\end{array}$ & $\begin{array}{c}\text { F1 } \\
9\end{array}$ & $\mathrm{G}$ & $\mathrm{H}$ & $\begin{array}{l}\text { I } \\
6\end{array}$ & $\begin{array}{l}\mathrm{J} \\
1\end{array}$ & $\begin{array}{l}\mathrm{K} \\
5\end{array}$ & L6 & M6 & N1 & 07 & P1 & $\begin{array}{c}\text { Q1 } \\
9\end{array}$ & $\begin{array}{c}\text { R1 } \\
1\end{array}$ & $\begin{array}{c}\text { S1 } \\
7\end{array}$ & $\begin{array}{c}\text { T1 } \\
9\end{array}$ & U1 & $\begin{array}{c}\text { V1 } \\
0\end{array}$ & $\begin{array}{c}\text { W1 } \\
6\end{array}$ & $\begin{array}{c}\mathrm{X} 1 \\
6\end{array}$ & Y13 & Z15 & $\begin{array}{c}0.8 \\
2\end{array}$ \\
\hline $\begin{array}{l}\text { A } \\
5\end{array}$ & B9 & C7 & $\begin{array}{c}\text { D1 } \\
6\end{array}$ & $\begin{array}{c}\text { E1 } \\
5\end{array}$ & F8 & G & $\begin{array}{l}\mathrm{H} \\
2\end{array}$ & $\begin{array}{l}\text { I } \\
6 \\
\end{array}$ & $\begin{array}{l} \\
1 \\
\end{array}$ & $\begin{array}{l}\mathrm{K} \\
5\end{array}$ & & $\begin{array}{c}\text { M1 } \\
4\end{array}$ & N6 & 03 & P7 & $\begin{array}{c}1 \\
6\end{array}$ & $\begin{array}{c}\text { R1 } \\
3\end{array}$ & $\begin{array}{c}\text { S1 } \\
6\end{array}$ & T6 & $\begin{array}{c}\text { U1 } \\
2\end{array}$ & V8 & $\begin{array}{c}\text { W1 } \\
4\end{array}$ & $\begin{array}{c}\mathrm{X} 1 \\
5\end{array}$ & Y10 & Z17 & $\begin{array}{c}0.8 \\
2\end{array}$ \\
\hline $\begin{array}{l}\text { A } \\
5 \\
\end{array}$ & B8 & C7 & D2 & E1 & $\begin{array}{c}\mathrm{F} 1 \\
1 \\
\end{array}$ & $G$ & $\begin{array}{l}\mathrm{H} \\
2 \\
\end{array}$ & $\begin{array}{l}\text { I } \\
6 \\
\end{array}$ & $\begin{array}{l}J \\
1 \\
\end{array}$ & $\begin{array}{l}\mathrm{K} \\
5 \\
\end{array}$ & L1 & M2 & N8 & 04 & P5 & Q7 & R4 & $\begin{array}{c}\text { S1 } \\
3\end{array}$ & T7 & U4 & $\begin{array}{c}\text { V1 } \\
7\end{array}$ & W2 & X2 & Y16 & $\mathrm{Z} 15$ & $\begin{array}{c}0.8 \\
2\end{array}$ \\
\hline $\begin{array}{l}\text { A } \\
5\end{array}$ & B7 & C5 & D1 & $\begin{array}{c}\text { E1 } \\
3\end{array}$ & $\begin{array}{c}\mathrm{F} 1 \\
1\end{array}$ & G & $\mathrm{H}$ & $\begin{array}{l}\text { I } \\
6\end{array}$ & $\begin{array}{l} \\
1\end{array}$ & $\begin{array}{l}\mathrm{K} \\
5\end{array}$ & L1 & $\begin{array}{c}\text { M1 } \\
0\end{array}$ & N5 & 04 & P6 & Q5 & R1 & S8 & T9 & $\begin{array}{c}\text { U1 } \\
4\end{array}$ & $\begin{array}{c}\text { V2 } \\
0\end{array}$ & $\begin{array}{c}\text { W1 } \\
5\end{array}$ & X8 & Y14 & Z12 & $\begin{array}{c}0.8 \\
2\end{array}$ \\
\hline $\begin{array}{l}\text { A } \\
5\end{array}$ & $\begin{array}{c}\text { B1 } \\
2\end{array}$ & C8 & $\begin{array}{c}\text { D1 } \\
6\end{array}$ & $\begin{array}{c}\text { E1 } \\
5\end{array}$ & $\begin{array}{c}\mathrm{F} 1 \\
0\end{array}$ & & $\overline{\mathrm{H}}$ & $\begin{array}{l}\mathrm{I} \\
6\end{array}$ & $\begin{array}{l} \\
1 \\
\end{array}$ & $\begin{array}{l}\mathrm{K} \\
5\end{array}$ & L7 & M8 & N1 & 04 & P1 & Q5 & $\begin{array}{c}\text { R1 } \\
8\end{array}$ & S1 & T8 & $\begin{array}{c}\text { U1 } \\
5\end{array}$ & V3 & W3 & X3 & Y16 & Z5 & $\begin{array}{c}0.8 \\
2\end{array}$ \\
\hline $\begin{array}{l}\text { A } \\
6\end{array}$ & $\begin{array}{c}\text { B1 } \\
8\end{array}$ & $\begin{array}{c}\mathrm{C} 2 \\
0\end{array}$ & $\begin{array}{c}\text { D1 } \\
7\end{array}$ & $\begin{array}{c}\text { E1 } \\
7\end{array}$ & $\begin{array}{c}\text { F1 } \\
6\end{array}$ & $G$ & $\mathrm{H}$ & $\begin{array}{l}\mathrm{I} \\
7\end{array}$ & $\begin{array}{l}\mathrm{J} \\
8\end{array}$ & $\begin{array}{l}\mathrm{K} \\
3\end{array}$ & L9 & $\begin{array}{c}\text { M1 } \\
3\end{array}$ & N9 & $\begin{array}{c}01 \\
2\end{array}$ & $\begin{array}{c}\text { P1 } \\
8\end{array}$ & $\begin{array}{c}\mathrm{Q} 2 \\
0\end{array}$ & $\begin{array}{c}\text { R1 } \\
9\end{array}$ & $\begin{array}{c}\text { S1 } \\
7\end{array}$ & $\begin{array}{c}\text { T1 } \\
6\end{array}$ & U2 & V2 & W8 & $\begin{array}{c}\mathrm{X} 1 \\
5\end{array}$ & Y8 & $\mathrm{Z} 2$ & $\begin{array}{c}0.8 \\
8\end{array}$ \\
\hline $\begin{array}{l}A \\
6\end{array}$ & $\begin{array}{c}\text { B1 } \\
6\end{array}$ & $\begin{array}{c}\text { C1 } \\
9\end{array}$ & $\begin{array}{c}\text { D1 } \\
6\end{array}$ & $\begin{array}{c}\text { E1 } \\
7\end{array}$ & $\begin{array}{l}F_{5} \\
5\end{array}$ & 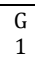 & $\mathrm{H}$ & $\begin{array}{l}\text { I } \\
7\end{array}$ & $\begin{array}{l}J \\
8\end{array}$ & $\begin{array}{l}\mathrm{K} \\
3\end{array}$ & L9 & $\begin{array}{c}\text { M1 } \\
1\end{array}$ & N7 & 09 & $\begin{array}{c}\text { P1 } \\
6\end{array}$ & $\begin{array}{c}\text { Q1 } \\
9\end{array}$ & $\begin{array}{c}\text { R1 } \\
4\end{array}$ & $\begin{array}{c}\text { S1 } \\
7\end{array}$ & $\begin{array}{c}\text { T1 } \\
6\end{array}$ & U6 & V6 & W8 & X8 & Y8 & $\mathrm{Z7}$ & $\begin{array}{c}0.8 \\
8\end{array}$ \\
\hline $\begin{array}{l}\text { A } \\
6\end{array}$ & $\begin{array}{c}\text { B1 } \\
2\end{array}$ & $\begin{array}{c}\mathrm{C} 1 \\
5\end{array}$ & $\begin{array}{c}\text { D1 } \\
5\end{array}$ & $\begin{array}{c}\text { E1 } \\
3\end{array}$ & $\begin{array}{l}\mathrm{F} \\
1\end{array}$ & 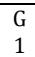 & $\mathrm{H}$ & $\begin{array}{l}\text { I } \\
7\end{array}$ & $\mathrm{~J}$ & $\begin{array}{l}\mathrm{K} \\
3\end{array}$ & L8 & M9 & $\begin{array}{c}\mathrm{N} 1 \\
8\end{array}$ & 09 & $\begin{array}{c}\text { P1 } \\
6\end{array}$ & $\begin{array}{c}\text { Q1 } \\
6\end{array}$ & $\begin{array}{c}\text { R1 } \\
6\end{array}$ & & $\begin{array}{c}\text { T1 } \\
5\end{array}$ & $\begin{array}{c}\text { U1 } \\
5\end{array}$ & V5 & N7 & X9 & Y10 & Z3 & $\begin{array}{c}0.8 \\
8\end{array}$ \\
\hline $\begin{array}{l}\text { A } \\
6\end{array}$ & $\begin{array}{c}\text { B2 } \\
0\end{array}$ & $\begin{array}{c}\mathrm{C} 1 \\
0\end{array}$ & $\begin{array}{c}\text { D1 } \\
6\end{array}$ & $\begin{array}{c}\text { E1 } \\
5\end{array}$ & $\begin{array}{l}F \\
9\end{array}$ & $\mathrm{c}$ & $\mathrm{H}$ & $\begin{array}{l}\text { I } \\
7\end{array}$ & $\begin{array}{l}J \\
8 \\
\end{array}$ & $\begin{array}{l}\mathrm{K} \\
3 \\
\end{array}$ & $\mathrm{~L}$ & M3 & $\begin{array}{c}\text { N1 } \\
9\end{array}$ & 05 & $\begin{array}{c}\text { P1 } \\
9\end{array}$ & $\begin{array}{c}\text { Q1 } \\
5\end{array}$ & $\begin{array}{c}\text { R1 } \\
1\end{array}$ & $\begin{array}{c}\text { S1 } \\
8\end{array}$ & $\begin{array}{c}\text { T1 } \\
9\end{array}$ & $\mathrm{~L}$ & $\begin{array}{c}\text { V1 } \\
0\end{array}$ & N6 & X6 & Y1 & Z3 & $\begin{array}{c}0.8 \\
8\end{array}$ \\
\hline $\begin{array}{l}\text { A } \\
6 \\
\end{array}$ & $\begin{array}{c}\text { B1 } \\
0\end{array}$ & $\begin{array}{c}\text { C1 } \\
3\end{array}$ & $\begin{array}{c}\text { D1 } \\
1\end{array}$ & $\begin{array}{c}\text { E1 } \\
7\end{array}$ & $\begin{array}{c}\text { F1 } \\
0\end{array}$ & 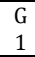 & $\mathrm{H}$ & $\begin{array}{l}\text { I } \\
7\end{array}$ & $\begin{array}{l}J \\
8 \\
\end{array}$ & $\begin{array}{l}\mathrm{K} \\
3 \\
\end{array}$ & & $\begin{array}{c}\text { M1 } \\
3\end{array}$ & N8 & 07 & P9 & $\begin{array}{c}\text { Q1 } \\
2\end{array}$ & $\begin{array}{c}\text { R1 } \\
1\end{array}$ & S7 & T9 & U7 & V9 & $\begin{array}{c}\text { W1 } \\
3\end{array}$ & $\begin{array}{c}\mathrm{X} 1 \\
4\end{array}$ & Y14 & Z18 & $\begin{array}{c}0.8 \\
8\end{array}$ \\
\hline $\begin{array}{l}\text { A } \\
6\end{array}$ & $\begin{array}{c}\text { B1 } \\
3\end{array}$ & $\begin{array}{c}\text { C1 } \\
4\end{array}$ & $\begin{array}{c}\mathrm{D} 2 \\
0\end{array}$ & E8 & F7 & $\begin{array}{l}\mathrm{G} \\
1\end{array}$ & $\begin{array}{l}\mathrm{H} \\
1\end{array}$ & $\begin{array}{l}\text { I } \\
7\end{array}$ & $\begin{array}{l}J \\
8\end{array}$ & $\begin{array}{l}\mathrm{K} \\
3\end{array}$ & $\begin{array}{c}\text { L1 } \\
4\end{array}$ & $\begin{array}{c}\text { M1 } \\
9\end{array}$ & N9 & 02 & $\begin{array}{c}\text { P1 } \\
0\end{array}$ & $\begin{array}{c}\text { Q1 } \\
3\end{array}$ & $\begin{array}{c}\text { R2 } \\
0\end{array}$ & 5 & T3 & $\begin{array}{c}\text { U1 } \\
6\end{array}$ & V1 & $\begin{array}{c}\text { W1 } \\
4\end{array}$ & $\begin{array}{c}\mathrm{X} 2 \\
0\end{array}$ & Y6 & Z3 & $\begin{array}{c}0.8 \\
8\end{array}$ \\
\hline $\begin{array}{l}\text { A } \\
6\end{array}$ & $\begin{array}{c}\text { B1 } \\
7\end{array}$ & $\begin{array}{c}\text { C1 } \\
0\end{array}$ & $\begin{array}{c}\text { D1 } \\
6\end{array}$ & E8 & $\begin{array}{c}\text { F1 } \\
5\end{array}$ & G & $\begin{array}{l}\mathrm{H} \\
1\end{array}$ & $\begin{array}{l}\text { I } \\
7\end{array}$ & $\begin{array}{l}J \\
8\end{array}$ & $\begin{array}{l}\mathrm{K} \\
3\end{array}$ & L2 & M2 & N8 & $\begin{array}{c}01 \\
4\end{array}$ & $\begin{array}{c}\text { P1 } \\
7\end{array}$ & $\begin{array}{c}\text { Q1 } \\
0\end{array}$ & $\begin{array}{c}\text { R1 } \\
8\end{array}$ & S7 & $\begin{array}{c}\mathrm{T} 1 \\
6\end{array}$ & $\begin{array}{c}\mathrm{U} 1 \\
2\end{array}$ & V3 & W4 & X5 & Y18 & $\mathrm{Z} 2$ & $\begin{array}{c}0.8 \\
8\end{array}$ \\
\hline $\begin{array}{l}\text { A } \\
6\end{array}$ & B6 & C7 & D3 & $\begin{array}{c}\text { E1 } \\
8\end{array}$ & F9 & 1 & $\begin{array}{l}\mathrm{H} \\
1\end{array}$ & $\begin{array}{l}\text { I } \\
7\end{array}$ & $\begin{array}{l} \\
8 \\
\end{array}$ & $\begin{array}{l}\mathrm{K} \\
3\end{array}$ & & $\begin{array}{c}\text { M1 } \\
5\end{array}$ & $\begin{array}{c}\mathrm{N} 1 \\
0\end{array}$ & 08 & P6 & Q7 & R3 & & T8 & U7 & & & $\begin{array}{c}\mathrm{X} 1 \\
4\end{array}$ & Y6 & $\mathrm{Z} 10$ & $\begin{array}{c}0.8 \\
8\end{array}$ \\
\hline $\begin{array}{l}\text { A } \\
6\end{array}$ & B5 & C7 & $\begin{array}{c}\mathrm{D} 1 \\
3\end{array}$ & $\begin{array}{c}\text { E1 } \\
5\end{array}$ & F5 & $\begin{array}{l}G \\
1\end{array}$ & $\begin{array}{l}\mathrm{H} \\
1\end{array}$ & $\begin{array}{l}\text { I } \\
7\end{array}$ & $\begin{array}{l}J \\
8\end{array}$ & $\begin{array}{l}\mathrm{K} \\
3\end{array}$ & L8 & M7 & N5 & $\begin{array}{c}01 \\
6\end{array}$ & P5 & Q6 & $\begin{array}{c}\text { R1 } \\
8\end{array}$ & $\begin{array}{c}\mathrm{S} 1 \\
2\end{array}$ & T3 & $\begin{array}{c}\text { U1 } \\
6\end{array}$ & V3 & W6 & $\begin{array}{c}\mathrm{X} 1 \\
1\end{array}$ & Y5 & $\mathrm{Z} 4$ & $\begin{array}{c}0.8 \\
8\end{array}$ \\
\hline $\begin{array}{l}A \\
6\end{array}$ & $\begin{array}{c}\text { B1 } \\
8\end{array}$ & $\begin{array}{c}\text { C1 } \\
3\end{array}$ & $\begin{array}{c}\text { D1 } \\
5\end{array}$ & E3 & $\begin{array}{c}\mathrm{F} 1 \\
8\end{array}$ & $\mathrm{G}$ & $\begin{array}{l}\mathrm{H} \\
1\end{array}$ & $\begin{array}{l}\text { I } \\
7\end{array}$ & $\begin{array}{l}J \\
8\end{array}$ & $\begin{array}{l}\mathrm{K} \\
3\end{array}$ & & $\begin{array}{c}\text { M1 } \\
6\end{array}$ & N1 & $\begin{array}{c}01 \\
1\end{array}$ & $\begin{array}{c}\text { P1 } \\
8\end{array}$ & Q6 & $\begin{array}{c}\text { R1 } \\
5\end{array}$ & S3 & $\begin{array}{c}\text { T1 } \\
8\end{array}$ & $\begin{array}{c}\mathrm{U} 1 \\
0\end{array}$ & V6 & $\begin{array}{c}\text { W1 } \\
3\end{array}$ & $\begin{array}{c}\mathrm{X} 1 \\
8\end{array}$ & Y17 & Z3 & $\begin{array}{c}0.8 \\
8\end{array}$ \\
\hline $\begin{array}{l}A \\
6\end{array}$ & B3 & $\mathrm{C} 2$ & D3 & $\begin{array}{c}\text { E1 } \\
9\end{array}$ & F5 & $\mathrm{G}$ & $\begin{array}{l}\mathrm{H} \\
1\end{array}$ & $\begin{array}{l}\text { I } \\
7\end{array}$ & \begin{tabular}{|l}
$\mathrm{J}$ \\
8
\end{tabular} & $\begin{array}{l}\mathrm{K} \\
3\end{array}$ & L1 & $\begin{array}{c}\text { M1 } \\
3\end{array}$ & $\begin{array}{c}\text { N1 } \\
1\end{array}$ & $\begin{array}{c}01 \\
1\end{array}$ & P4 & Q2 & R2 & S1 & T5 & U6 & $\begin{array}{c}\text { V1 } \\
8\end{array}$ & $\begin{array}{c}\text { W1 } \\
7\end{array}$ & $\begin{array}{c}1 \\
3\end{array}$ & Y13 & Z9 & $\begin{array}{c}0.8 \\
8\end{array}$ \\
\hline $\begin{array}{l}\text { A } \\
6\end{array}$ & B6 & C3 & D6 & E1 & F8 & $\begin{array}{l}G \\
1\end{array}$ & $\begin{array}{l}\mathrm{H} \\
1\end{array}$ & $\begin{array}{l}\text { I } \\
7\end{array}$ & $\begin{array}{l}J \\
8 \\
\end{array}$ & $\begin{array}{l}\mathrm{K} \\
3\end{array}$ & L1 & $\begin{array}{c}\text { M1 } \\
6\end{array}$ & $\begin{array}{c}\text { N1 } \\
9\end{array}$ & $\begin{array}{c}01 \\
8\end{array}$ & P9 & Q6 & $\begin{array}{c}\text { R1 } \\
3\end{array}$ & S1 & $\mathrm{T} 8$ & $\begin{array}{c}\mathrm{U} 1 \\
1\end{array}$ & V7 & $\begin{array}{c}\text { W1 } \\
0\end{array}$ & $\begin{array}{c}\mathrm{X} 1 \\
6\end{array}$ & Y2 & $\mathrm{Z} 1$ & $\begin{array}{c}0.8 \\
8\end{array}$ \\
\hline $\begin{array}{l}\text { A } \\
6\end{array}$ & $\begin{array}{c}\text { B2 } \\
0\end{array}$ & C7 & D2 & $\begin{array}{c}\text { E1 } \\
6\end{array}$ & $\begin{array}{c}\mathrm{F} 2 \\
0\end{array}$ & G & $\begin{array}{l}\mathrm{H} \\
1\end{array}$ & $\begin{array}{l}\text { I } \\
7\end{array}$ & $\begin{array}{l}J \\
8 \\
\end{array}$ & $\begin{array}{l}\mathrm{K} \\
3\end{array}$ & $\begin{array}{c}\text { L1 } \\
4\end{array}$ & M8 & $\mathrm{N} 2$ & 03 & $\begin{array}{c}\text { P1 } \\
8\end{array}$ & Q5 & R2 & & $\begin{array}{c}\mathrm{T} 2 \\
0\end{array}$ & U2 & $\begin{array}{c}\text { V1 } \\
8\end{array}$ & W3 & X8 & Y3 & $\mathrm{Z} 2$ & $\begin{array}{c}0.8 \\
8\end{array}$ \\
\hline $\begin{array}{l}\text { A } \\
7\end{array}$ & $\begin{array}{c}\text { B1 } \\
4\end{array}$ & $\begin{array}{c}\text { C1 } \\
3\end{array}$ & D4 & E5 & $\begin{array}{c}\text { F1 } \\
6\end{array}$ & $\begin{array}{l}G \\
3\end{array}$ & $\begin{array}{l}\mathrm{H} \\
6\end{array}$ & $\begin{array}{l}\text { I } \\
4 \\
\end{array}$ & $\begin{array}{l} \\
4 \\
\end{array}$ & $\begin{array}{l}\mathrm{K} \\
6\end{array}$ & L6 & M5 & $\begin{array}{c}\text { N1 } \\
6\end{array}$ & 08 & $\begin{array}{c}\mathrm{P} 1 \\
3\end{array}$ & $\begin{array}{c}\text { Q1 } \\
4\end{array}$ & $\begin{array}{c}\text { R1 } \\
1\end{array}$ & S4 & $\begin{array}{c}\text { T1 } \\
3\end{array}$ & $\begin{array}{c}\text { U1 } \\
5\end{array}$ & V9 & $\begin{array}{c}\text { W1 } \\
2\end{array}$ & $\begin{array}{c}\mathrm{X} 1 \\
2\end{array}$ & Y16 & $\mathrm{Z7}$ & $\begin{array}{c}0.9 \\
4\end{array}$ \\
\hline $\begin{array}{l}\text { A } \\
7\end{array}$ & B6 & $\begin{array}{c}\text { C1 } \\
4\end{array}$ & D7 & $\begin{array}{c}\text { E1 } \\
7\end{array}$ & F7 & $\begin{array}{l}\mathrm{G} \\
3\end{array}$ & $\begin{array}{l}\mathrm{H} \\
6\end{array}$ & $\begin{array}{l}\mathrm{I} \\
4\end{array}$ & $\mathrm{~J}$ & $\begin{array}{l}\mathrm{K} \\
6\end{array}$ & & $\begin{array}{c}\text { M1 } \\
9\end{array}$ & $\begin{array}{c}\text { N1 } \\
3\end{array}$ & 9 & P8 & $\begin{array}{c} \\
\text { 1 } \\
3\end{array}$ & R6 & & T9 & U9 & & $\begin{array}{c}\text { W1 } \\
9\end{array}$ & $\begin{array}{c}\mathrm{X} 1 \\
9\end{array}$ & Y15 & Z16 & $\begin{array}{c}0.9 \\
4\end{array}$ \\
\hline $\begin{array}{l}\text { A } \\
7\end{array}$ & $\begin{array}{c}\text { B1 } \\
4\end{array}$ & $\begin{array}{c}\text { C1 } \\
4\end{array}$ & D7 & $\begin{array}{c}\text { E1 } \\
2\end{array}$ & $\begin{array}{c}\mathrm{F} 1 \\
6\end{array}$ & $\begin{array}{l}G \\
3\end{array}$ & $\begin{array}{l}\mathrm{H} \\
6\end{array}$ & $\begin{array}{l}\text { I } \\
4\end{array}$ & $\begin{array}{l}\mathrm{J} \\
4\end{array}$ & $\begin{array}{l}\mathrm{K} \\
6\end{array}$ & L5 & M4 & $\begin{array}{c}\text { N1 } \\
3\end{array}$ & 03 & 2 & $\begin{array}{c}1 \\
3\end{array}$ & R8 & $\begin{array}{c}\text { S1 } \\
0\end{array}$ & $\begin{array}{c}\text { T1 } \\
3\end{array}$ & & $\begin{array}{c}\text { V1 } \\
3\end{array}$ & $\begin{array}{c}\text { W1 } \\
4\end{array}$ & $\begin{array}{c}\mathrm{X} 1 \\
2\end{array}$ & Y9 & $\mathrm{Z7}$ & $\begin{array}{c}0.9 \\
4\end{array}$ \\
\hline $\begin{array}{l}\text { A } \\
7\end{array}$ & $\begin{array}{c}\text { B1 } \\
4\end{array}$ & $\begin{array}{l}\mathrm{C} \\
5\end{array}$ & $\begin{array}{c}\text { D1 } \\
3\end{array}$ & E6 & $\begin{array}{c}\text { F1 } \\
4\end{array}$ & $\begin{array}{l}\mathrm{G} \\
3\end{array}$ & $\begin{array}{l}\mathrm{H} \\
6\end{array}$ & $\begin{array}{l} \\
4\end{array}$ & $\begin{array}{l}\mathrm{J} \\
4\end{array}$ & $\begin{array}{l}\mathrm{K} \\
6\end{array}$ & & $\begin{array}{c}\text { M1 } \\
4\end{array}$ & N5 & 01 & $\begin{array}{c}\text { P1 } \\
0\end{array}$ & $\begin{array}{c}\text { Q1 } \\
3\end{array}$ & $\begin{array}{c}\text { R1 } \\
0\end{array}$ & S8 & $\begin{array}{c}\text { T1 } \\
0\end{array}$ & $\begin{array}{c}\text { U1 } \\
0\end{array}$ & $\begin{array}{c}\text { V1 } \\
0\end{array}$ & $\begin{array}{c}\text { W1 } \\
8\end{array}$ & $\begin{array}{c}\mathrm{X} 1 \\
8\end{array}$ & Y7 & Z11 & $\begin{array}{c}0.9 \\
4\end{array}$ \\
\hline $\begin{array}{l}\text { A } \\
7\end{array}$ & B9 & $\begin{array}{c}\text { C1 } \\
3\end{array}$ & $\begin{array}{c}\text { D1 } \\
7\end{array}$ & $\begin{array}{c}\text { E1 } \\
5\end{array}$ & F6 & $\begin{array}{l}G \\
3\end{array}$ & $\begin{array}{l}\mathrm{H} \\
6\end{array}$ & $\begin{array}{l}\text { I } \\
4\end{array}$ & $\begin{array}{l}\mathrm{J} \\
4\end{array}$ & $\begin{array}{l}\mathrm{K} \\
6\end{array}$ & L4 & M4 & N7 & $\begin{array}{c}01 \\
3\end{array}$ & P8 & $\begin{array}{c}\text { Q1 } \\
1\end{array}$ & $\begin{array}{c}\text { R1 } \\
3\end{array}$ & $\begin{array}{c}\text { S1 } \\
2\end{array}$ & T7 & $\begin{array}{c}\text { U1 } \\
5\end{array}$ & V7 & W7 & X6 & Y10 & $\mathrm{Z7}$ & $\begin{array}{c}0.9 \\
4\end{array}$ \\
\hline $\mathrm{A}$ & $\begin{array}{c}\text { B1 } \\
4\end{array}$ & C9 & D8 & $\begin{array}{c}\text { E1 } \\
7\end{array}$ & F1 & $\begin{array}{l}\mathrm{G} \\
3\end{array}$ & $\mathrm{H}$ & $\begin{array}{l} \\
\end{array}$ & $\mathrm{J}$ & $\begin{array}{l}\mathrm{K} \\
6\end{array}$ & L4 & M3 & $\begin{array}{c}\text { N1 } \\
7\end{array}$ & 02 & $\begin{array}{c}\mathrm{P} 1 \\
1\end{array}$ & $\begin{array}{c} \\
\text { Q1 } \\
1\end{array}$ & R8 & $\begin{array}{c}\text { S1 } \\
7\end{array}$ & $\begin{array}{c}\text { T1 } \\
2\end{array}$ & U2 & $\begin{array}{c}\text { V1 } \\
2\end{array}$ & $\begin{array}{c}\text { W1 } \\
7\end{array}$ & $\begin{array}{c}\mathrm{X} 1 \\
6\end{array}$ & Y9 & $\mathrm{Z} 5$ & $\begin{array}{c}0.9 \\
4\end{array}$ \\
\hline
\end{tabular}




\begin{tabular}{|c|c|c|c|c|c|c|c|c|c|c|c|c|c|c|c|c|c|c|c|c|c|c|c|c|c|c|}
\hline $\begin{array}{l}\text { A } \\
7\end{array}$ & & $\begin{array}{c}\mathrm{C} 1 \\
2\end{array}$ & & & $\begin{array}{l}71 \\
5\end{array}$ & $\begin{array}{l}\text { G } \\
3\end{array}$ & 6 & $\begin{array}{l}\text { I } \\
4\end{array}$ & $\begin{array}{l}J \\
4\end{array}$ & $\begin{array}{l}K \\
6\end{array}$ & $\begin{array}{c}\text { L1 } \\
1\end{array}$ & M9 & N4 & $\begin{array}{c}01 \\
0\end{array}$ & $\begin{array}{c}\mathrm{P} 1 \\
4\end{array}$ & Q & $\begin{array}{c}\text { R1 } \\
1\end{array}$ & 7 & $\begin{array}{l}\text { T1 } \\
5\end{array}$ & $\begin{array}{c}\text { U1 } \\
6\end{array}$ & $\begin{array}{c}\mathrm{V} 1 \\
0\end{array}$ & W9 & X8 & Y13 & Z14 & $\begin{array}{c}0.9 \\
4\end{array}$ \\
\hline A & B9 & $\begin{array}{c}\mathrm{C} 1 \\
1\end{array}$ & D2 & $\mathrm{E} 1$ & $\begin{array}{c}\text { F1 } \\
2\end{array}$ & G & & $\begin{array}{l}\text { I } \\
4\end{array}$ & $\begin{array}{l}\mathrm{J} \\
4\end{array}$ & $\begin{array}{l}\mathrm{K} \\
6\end{array}$ & $\begin{array}{c}\text { L1 } \\
9\end{array}$ & $\begin{array}{c}\text { M1 } \\
7\end{array}$ & N6 & $\begin{array}{c}01 \\
0\end{array}$ & P7 & Q1 & R4 & 51 & T9 & $\begin{array}{c}\mathrm{U} 1 \\
1\end{array}$ & & $\begin{array}{c}\text { W1 } \\
9\end{array}$ & $\begin{array}{c}\mathrm{X} 1 \\
8\end{array}$ & 11 & 10 & $\begin{array}{c}0.9 \\
4\end{array}$ \\
\hline A & B1 & $\begin{array}{c}\text { C1 } \\
0\end{array}$ & & $\mathrm{E}$ & & & & $\begin{array}{l}\text { I } \\
4\end{array}$ & $\begin{array}{l}\mathrm{J} \\
4\end{array}$ & $\mathrm{~K}$ & L1 & M6 & N5 & 05 & $\overline{\mathrm{P} 1}$ & Q9 & R4 & S1 & T1 & $\begin{array}{c}\mathrm{U} 1 \\
1\end{array}$ & V1 & $\begin{array}{l}\text { W1 } \\
4\end{array}$ & $\mathrm{X} 1$ & Y12 & Z8 & $\begin{array}{c}0.9 \\
4\end{array}$ \\
\hline $\begin{array}{l}\text { A } \\
7\end{array}$ & B4 & C6 & D2 & $\begin{array}{l}\text { E1 } \\
9\end{array}$ & F8 & $\overline{\mathrm{G}}$ & $\overline{\mathrm{H}}$ & $\begin{array}{l}\text { I } \\
4\end{array}$ & $\begin{array}{l}\mathrm{J} \\
4\end{array}$ & $\begin{array}{l}\mathrm{K} \\
6\end{array}$ & $\begin{array}{c}\text { L1 } \\
9\end{array}$ & $\begin{array}{c}\text { M1 } \\
8\end{array}$ & N1 & $\begin{array}{c}01 \\
5\end{array}$ & P5 & Q7 & R1 & S1 & $\mathrm{T} 8$ & U7 & $\begin{array}{c}\text { V1 } \\
9\end{array}$ & $\begin{array}{c}\text { W1 } \\
6\end{array}$ & $\begin{array}{c}\mathrm{X} 1 \\
1\end{array}$ & Y13 & Z6 & $\begin{array}{c}0.9 \\
4\end{array}$ \\
\hline $\begin{array}{l}\text { A } \\
7\end{array}$ & B9 & C8 & & E2 & F6 & 0 & & $\begin{array}{l}\mathrm{I} \\
4\end{array}$ & $\begin{array}{l}\mathrm{J} \\
4\end{array}$ & $\begin{array}{l}\mathrm{K} \\
6\end{array}$ & L8 & $\begin{array}{c}\text { M1 } \\
3\end{array}$ & N7 & $\begin{array}{c}01 \\
2\end{array}$ & P8 & Q8 & R1 & S2 & T5 & U9 & V3 & $\begin{array}{c}\text { W1 } \\
3\end{array}$ & $\begin{array}{c}\mathrm{X} 1 \\
8\end{array}$ & Y & Z11 & $\begin{array}{c}0.9 \\
4\end{array}$ \\
\hline $\begin{array}{l}\mathrm{A} \\
7\end{array}$ & & C6 & $\begin{array}{c}\mathrm{D} 1 \\
3\end{array}$ & E1 & $\begin{array}{c}\text { F1 } \\
5\end{array}$ & 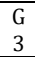 & & $\begin{array}{l}\text { I } \\
4\end{array}$ & $\begin{array}{l}\mathrm{J} \\
4\end{array}$ & $\begin{array}{l}K \\
6 \\
\end{array}$ & L7 & M8 & & 03 & P1 & Q6 & R1 & S1 & $\begin{array}{c}\mathrm{T} 1 \\
4\end{array}$ & U2 & V8 & W4 & X4 & Y9 & $\mathrm{Z} 12$ & $\begin{array}{c}0.9 \\
4\end{array}$ \\
\hline $\mathrm{A}$ & B4 & C4 & $\begin{array}{l}\mathrm{D} \\
2\end{array}$ & E2 & F4 & & & $\begin{array}{l}\text { I } \\
4\end{array}$ & $\begin{array}{l}\mathrm{J} \\
4\end{array}$ & $\begin{array}{l}\mathrm{K} \\
6\end{array}$ & $\begin{array}{c}\text { L1 } \\
1\end{array}$ & $\begin{array}{c}\text { M1 } \\
0\end{array}$ & $\mathrm{~N}$ & 07 & P3 & Q5 & R9 & S4 & T3 & $\begin{array}{c}\mathrm{U} 1 \\
5\end{array}$ & $\begin{array}{c}\mathrm{V} 1 \\
1\end{array}$ & $\begin{array}{c}\text { W1 } \\
9\end{array}$ & $\begin{array}{c}\mathrm{X} 1 \\
8\end{array}$ & Y9 & Z6 & $\begin{array}{c}0.9 \\
4\end{array}$ \\
\hline $\mathrm{A}$ & & & & E8 & 4 & & & $\begin{array}{l}1 \\
5 \\
\end{array}$ & $\begin{array}{l} \\
2 \\
\end{array}$ & $\begin{array}{l}K \\
5 \\
\end{array}$ & L3 & M2 & N5 & 08 & & & & S & & $\begin{array}{c}\text { U1 } \\
4\end{array}$ & V1 & W3 & $\mathrm{X} 2$ & & & $\begin{array}{c}1.0 \\
0\end{array}$ \\
\hline$\overline{\mathrm{A}}$ & & $\begin{array}{l}\mathrm{C} \\
8\end{array}$ & & $\begin{array}{c}\bar{E} 1 \\
9\end{array}$ & & & & I & $\begin{array}{l}J \\
2\end{array}$ & $\begin{array}{l}\mathrm{K} \\
5\end{array}$ & $\begin{array}{c}\text { L1 } \\
1\end{array}$ & & & $\begin{array}{c}01 \\
3\end{array}$ & & 01 & & & & $\begin{array}{c}\mathrm{U} 1 \\
0\end{array}$ & V3 & $\begin{array}{c}\text { W1 } \\
0\end{array}$ & & & & $\begin{array}{c}1.0 \\
0\end{array}$ \\
\hline $\mathrm{A}$ & B & $\begin{array}{c}\mathrm{C} 1 \\
5\end{array}$ & & E & $\begin{array}{c}\text { F1 } \\
7\end{array}$ & 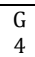 & & $\begin{array}{l}\text { I } \\
5\end{array}$ & $\begin{array}{l}J \\
2\end{array}$ & $\begin{array}{l}\mathrm{K} \\
5\end{array}$ & L3 & M3 & & 06 & & & & S & $\begin{array}{c}\text { T1 } \\
5\end{array}$ & U3 & V5 & W4 & X3 & & & $\begin{array}{c}1.0 \\
0\end{array}$ \\
\hline A & $\begin{array}{c}\mathrm{B} 1 \\
1\end{array}$ & $\begin{array}{c}\mathrm{C} 1 \\
4\end{array}$ & D1 & $\begin{array}{c}\text { E1 } \\
2\end{array}$ & $\begin{array}{c}\text { F1 } \\
6\end{array}$ & c & & $\begin{array}{l}\text { I } \\
5\end{array}$ & $\begin{array}{l}J \\
2\end{array}$ & $\begin{array}{l}\mathrm{K} \\
5\end{array}$ & $\begin{array}{c}\text { L1 } \\
9\end{array}$ & $\begin{array}{c}\text { M1 } \\
6\end{array}$ & N2 & 05 & $\begin{array}{c}\mathrm{P} 1 \\
0\end{array}$ & Q1 & R1 & S1 & T1 & $\begin{array}{c}\mathrm{U} 1 \\
4\end{array}$ & $\begin{array}{c}\text { V2 } \\
0\end{array}$ & W1 & 0 & $\mathrm{YU}$ & $\mathrm{ZU}$ & $\begin{array}{c}1.0 \\
0\end{array}$ \\
\hline $\begin{array}{l}\mathrm{A} \\
8\end{array}$ & $\begin{array}{c}\text { B1 } \\
8\end{array}$ & C9 & D2 & E6 & $\begin{array}{c}\text { F1 } \\
9\end{array}$ & $\begin{array}{l}G \\
4\end{array}$ & & $\begin{array}{l}\text { I } \\
5\end{array}$ & $\begin{array}{l}J \\
2\end{array}$ & $\begin{array}{l}\mathrm{K} \\
5\end{array}$ & $\begin{array}{c}\text { L1 } \\
1\end{array}$ & M6 & N3 & $\begin{array}{c}01 \\
1\end{array}$ & P1 & Q7 & R4 & S5 & T1 & U4 & $\begin{array}{c}\text { V1 } \\
6\end{array}$ & W6 & X5 & $\begin{array}{l}\mathrm{YU} \\
\mathrm{N}\end{array}$ & $\begin{array}{c}\mathrm{ZU} \\
\mathrm{N}\end{array}$ & $\begin{array}{c}1.0 \\
0\end{array}$ \\
\hline $\begin{array}{l}\mathrm{A} \\
8\end{array}$ & B5 & C4 & $\begin{array}{c}\mathrm{D} 1 \\
0\end{array}$ & $\begin{array}{r}\text { E1 } \\
6\end{array}$ & F6 & $\bar{G}$ & & $\begin{array}{l}\text { I } \\
5\end{array}$ & $\begin{array}{l} \\
2\end{array}$ & $\begin{array}{l}\mathrm{K} \\
5\end{array}$ & L5 & M4 & $\begin{array}{c}\mathrm{N} 1 \\
0\end{array}$ & 02 & P3 & Q5 & R1 & S7 & $\mathrm{T} 2$ & U3 & V3 & W1 & $\mathrm{X} 1$ & $\begin{array}{l}\mathrm{YU} \\
\mathrm{N}\end{array}$ & $\begin{array}{c}\mathrm{ZU} \\
\mathrm{N}\end{array}$ & $\begin{array}{c}1.0 \\
0\end{array}$ \\
\hline A & $\begin{array}{c}\text { B1 } \\
6\end{array}$ & C3 & D4 & $\begin{array}{c}\mathrm{E} 2 \\
0\end{array}$ & $\begin{array}{c}\text { F1 } \\
8\end{array}$ & C & & $\begin{array}{l}\text { I } \\
5\end{array}$ & $\begin{array}{l}J \\
2\end{array}$ & $\begin{array}{l}\mathrm{K} \\
5\end{array}$ & L2 & M2 & $\mathrm{N} 2$ & 05 & $\begin{array}{c}\mathrm{P} 1 \\
5\end{array}$ & Q2 & R5 & S5 & $\begin{array}{c}\text { T1 } \\
7\end{array}$ & $\begin{array}{c}\text { U1 } \\
6\end{array}$ & $\begin{array}{c}\text { V1 } \\
6\end{array}$ & W3 & X3 & $\begin{array}{l}\mathrm{YU} \\
\mathrm{N}\end{array}$ & $\begin{array}{c}\mathrm{ZU} \\
\mathrm{N}\end{array}$ & $\begin{array}{c}1.0 \\
0\end{array}$ \\
\hline$\vec{A}$ & B2 & C1 & D1 & $\begin{array}{c}E_{2} \\
0\end{array}$ & F3 & G & & $\begin{array}{l}\mathrm{I} \\
5\end{array}$ & $\begin{array}{l}\mathrm{J} \\
2\end{array}$ & $\begin{array}{l}\mathrm{K} \\
5\end{array}$ & $\begin{array}{l}\text { L1 } \\
9\end{array}$ & $\begin{array}{c}\text { M1 } \\
5\end{array}$ & & 01 & P2 & Q1 & R2 & $\begin{array}{c}\text { S1 } \\
5\end{array}$ & T3 & U5 & $\begin{array}{c}\text { V1 } \\
8\end{array}$ & W1 & X2 & $\begin{array}{l}\mathrm{YU} \\
\mathrm{N}\end{array}$ & $\begin{array}{c}\mathrm{ZU} \\
\mathrm{N}\end{array}$ & $\begin{array}{c}1.0 \\
0\end{array}$ \\
\hline
\end{tabular}

Source: Authors' own research. 